\title{
Significance of Exhaled Breath Test in Clinical Diagnosis: A Special Focus on the Detection of Diabetes Mellitus
}

\author{
Souvik $\operatorname{Das}^{1} \cdot$ Saurabh Pal $^{2} \cdot$ Madhuchhanda Mitra ${ }^{2}$
}

Received: 13 January 2016/ Accepted: 27 July 2016/Published online: 11 October 2016

(C) The Author(s) 2016. This article is published with open access at Springerlink.com

\begin{abstract}
Analysis of volatile organic compounds (VOCs) emanating from human exhaled breath can provide deep insight into the status of various biochemical processes in the human body. VOCs can serve as potential biomarkers of physiological and pathophysiological conditions related to several diseases. Breath VOC analysis, a noninvasive and quick biomonitoring approach, also has potential for the early detection and progress monitoring of several diseases. This paper gives an overview of the major VOCs present in human exhaled breath, possible biochemical pathways of breath VOC generation, diagnostic importance of their analysis, and analytical techniques used in the breath test. Breath analysis relating to diabetes mellitus and its characteristic breath biomarkers is focused on. Finally, some challenges and limitations of the breath test are discussed.
\end{abstract}

Keywords Breath analysis - Volatile organic compound . Disease diagnosis - Noninvasive method .

Breath biomarkers · Diabetes mellitus

\section{Introduction}

Bioinformation obtained from volatile organic compounds (VOCs) in the exhaled breath of humans can aid the early diagnosis of several diseases and can be used to decide

Madhuchhanda Mitra

madhuchhanda94@rediffmail.com

1 Department of Biomedical Engineering, JIS College of Engineering, Kalyani, West Bengal 741235, India

2 Department of Applied Physics, University of Calcutta, Kolkata, West Bengal 700009, India relevant medical therapies. The analysis of exhaled breath and associated VOCs has gained a considerable scientific, clinical, and research attention due to its potential in enabling the noninvasive observation of the biochemical processes of the human body [1-3]. The first initiatives of breath analysis for determining the physiological state of humans originated during the time of Hippocrates (460-370 $\mathrm{BC}$ ), when the ancient Greek physicians realized that some diseases could be diagnosed from the characteristic odor of patients' breath and knew that the human breath might provide sound information on health conditions [1-6]. In the period 1782-1783, Lavoisier for the first time analyzed the breath $\mathrm{CO}_{2}$ of Guinea pigs and showed that the gas is a product of combustion in the body [1,5]. Practically, it is not difficult for a skilled technician to recognize the characteristic 'fruity smell' of acetone, 'musty and fishy smell', 'urine-like smell', and 'putrid smell' in the breath of patients with diabetes, advanced liver disease, kidney failure, and lung abscess, respectively [1]. The analysis of VOCs present in exhaled breath can thus provide valuable information about the subjects' physiological and pathophysiological conditions. Such compounds can be useful indicators and potential biomarkers of various diseases and metabolic activities, facilitating disease diagnosis. It should be noted that biological monitoring is generally based on the analysis of blood. However, this involves an invasive and time-consuming technique, which is often unacceptable concerning patient care system. This invasive technique also needs skilled medical staff. Breath analysis is thus a very attractive alternative as it is a noninvasive and quick method that allows repeated sampling [1, 7].

A plethora of studies have reported the significance of analyzing VOCs in human breath [8-10]. In 1938, the 'drunkometer' was introduced as a roadside test of breathalcohol concentration [7, 11]. In the 1970s, Pauling et al. 
[12] used gas chromatography (GC) to detect more than 200 VOCs in human breath. Their contribution gave new insight into the human body and directed research in the analysis of VOCs for clinical diagnosis and therapeutic monitoring [2, 13, 14]. Since then, many studies have been carried out in this field. In 1997, Phillips [15] estimated 1259 VOCs from 20 normal healthy subjects using gas chromatography-mass spectrometry (GC/MS). In 1999, using GC/MS, Phillips et al. described 3481 VOCs in the breath gas of healthy controls, with an average number of about 200 VOCs detectable in an individual' breath gas [16]. Recently, 1765 VOCs of healthy humans have been published [5, 17].

Compounds in exhaled breath gas are generally classified as [3]:

1. Inorganic compounds, such as nitric oxide, oxygen, and carbon dioxide [18].

2. Exhaled breath condensate, which includes cytokines, hydrogen peroxide, isoprostanes, and leukotrienes [17].

3. VOCs, such as ethane, pentane, aldehydes, and isoprene [2, 18, 19].

In the context of the diagnosis of human diseases, a number of volatile biomarkers in exhaled breath have been reported [17, 18, 20-24]. It is essential to determine such biomarkers in order to monitor metabolic or any pathologic processes in the body. Expired breath VOCs that are commonly used for diagnostic purposes include oxygencontaining compounds (e.g., ethanol, methanol, 2-propanol, acetone, and acetaldehyde), hydrocarbons (e.g., ethane, pentane, and isoprene), sulfur-containing compounds (e.g., methyl mercaptanes, ethyl mercaptanes, and dimethyl sulfide), and nitrogen-containing substances (e.g., dimethylamine, trimethylamine, and ammonia) [2]. Acetone, isoprene, ethanol, methanol, other alcohols and alkanes have been reported to be the major identified VOCs $[3,25]$. A few of the above-mentioned types of breath VOC along with their possible biochemical pathways in the human body are discussed below.

\section{Origin and Biochemical Pathways of Major VOCs in Human Exhaled Breath}

\subsection{Oxygen-Containing Compounds}

Acetone is one of the major abundant VOCs in human breath [2, 26]. It should be emphasized here that acetone production in animals is believed to originate from two pathways: the decarboxylation of acetoacetate [2, 26-29] and the dehydrogenation of isopropanol or 2-propanol [27-30]. The first pathway, the major source of acetone production in mammals, arises from either lipolysis (lipid peroxidation) or amino acid degradation [2, 26-29]. Acetoacetate decarboxylation may occur both in an enzymecatalyzed manner and non-enzymatically. Studies on various rat tissues (e.g., kidney, liver, brain, placenta, and plasma) and human plasma [27, 29] have established the presence of enzymatic activity. Figure 1 illustrates the generation of acetone generated by hepatocytes via the decarboxylation of excess acetyl-coenzyme A (acetylCoA). The second metabolic pathway includes the dehydrogenation of 2-propanol (by liver alcohol dehydrogenase, $\mathrm{ADH})$ to acetone. This acetone is released mostly via urine and exhaled breath from the body. Acetone may also be further metabolized to acetate, formate, and carbon dioxide [30]. Acetone, a natural metabolic intermediate of lipolysis, is as a potential biomarker for monitoring the ketotic state of diabetic and fasting individuals, assessing fat loss, and measuring glucose levels [26].

In the human body, the origins of ethanol and methanol are not well understood [31-33]. However, these VOCs are believed to originate from microbial fermentation of the carbohydrates in the gastro-intestinal tract [31, 34-36]. Intestinal bacterial flora is regarded as an important source of breath ethanol [37] and methanol [38]. It has been proposed that methanol derives from S-adenosylmethionine in the pituitary or from the breakdown of ethanol by intestinal flora [32]. Usually, the breath ethanol concentrations in human subjects are much lower than those found in human breath after the intake of alcohol. It has also been postulated that an enzyme-mediated reduction of acetone forms 2-propanol in the body, implying that its

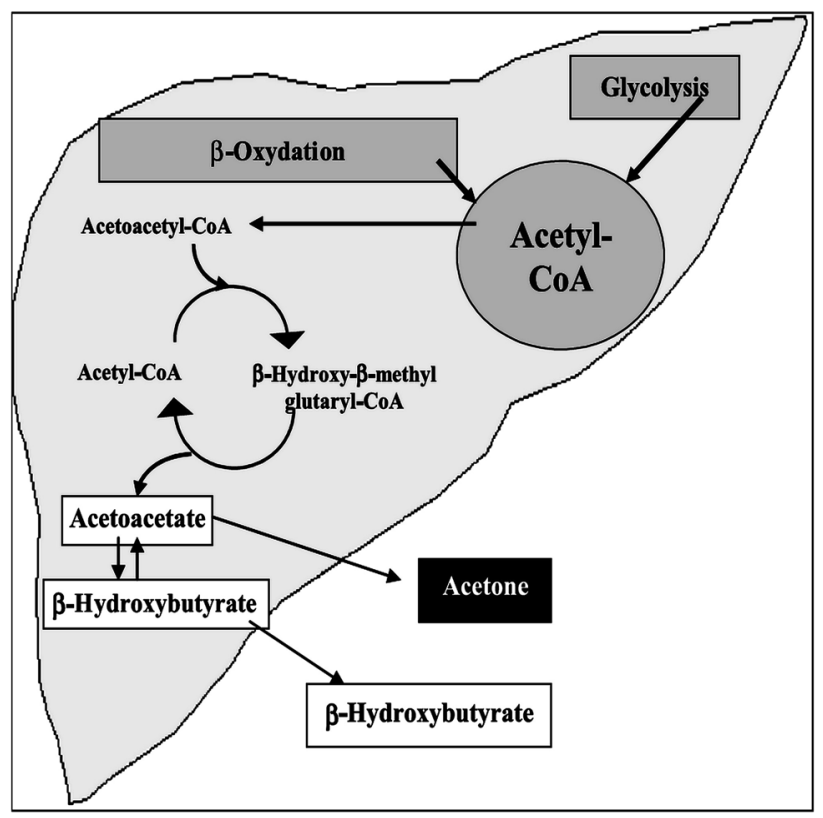

Fig. 1 Generation pathway of acetone in liver by hepatocytes [2] 
concentration in humans remain lower than acetone concentrations [38].

Researchers also claim ethanol and methanol to be mostly of microbial or exogenous origin [35]. Sources of exogenous methanol in the healthy human body include fruits, vegetables, and alcoholic beverages [35]. Methanol levels in breath may be influenced by intake of fruitderived pectin [36]. In a recent study on C57BL/6J mice revealed that methanol source strengths are barely affected by body mass. Rather, they are influenced by the diet matrix and a low-fat diet [36]. Regardless of the source, low levels of methanol are always maintained by the human physiological system [35].

Acetaldehyde originates as the first product, primarily in the liver during the metabolism of ethanol. Here, ethanol is oxidized by $\mathrm{ADH}$. The enzyme aldehyde dehydrogenase converts the produced acetaldehyde to acetate [39]. Breath acetaldehyde concentration is lower than ethanol concentration [2].

\subsection{Hydrocarbons}

\subsubsection{Saturated Hydrocarbons}

The major fractions of exhaled ethane and pentane are of systemic origin [2, 40]. These compounds are thought to originate from lipid peroxidation, a chain reaction that starts when an allylic hydrogen atom is eliminated by reactive oxygen species (ROS). The resulting radical is conjugated, peroxidized by oxygen, and undergoes further chemical reactions. The generation of ROS is described as the destructive aspect of oxidative stress [41]. In oxidative stress, cells are damaged as a result of a chemical reaction with oxidative agents (e.g., the superoxide anion or hydroxyl radical) [6, 42]. ROS bear free radicals and peroxides. These species may undergo further chemical changes and turn into more aggressive radical agents that can potentialy cause extensive cellular damage.

Saturated hydrocarbons, e.g., ethane and pentane, are produced from $\omega 3$ (e.g., linolenic acid) and $\omega 6$ fatty acids (e.g., linoleic and arachidonic acid), respectively (Fig. 2). These fatty acids have been described as the fundamental components of cell membranes [2, 6, 40, 43-45]. In vitro studies reveal that ethane and pentane originate when cell cultures are exposed to ROS. These aliphatic hydrocarbons are considered as in vitro and in vivo biomarkers of lipid peroxidation due to the close correlations between their exhalation and clinical conditions with high peroxidative activities, as suggested by various experimentations [46]. The levels of exhaled pentane and ethane are closely linked to other lipid peroxidation markers such as thiobarbituric acid reactive substances (e.g., malondialdehyde) [33]. Protein oxidation and colonic bacterial metabolism, despite being other important sources of hydrocarbons in the human body, have less potential in a hydrocarbon breath test for ethane and pentane [43]. Methylated hydrocarbons are also considered lipid peroxidation markers [2, 47, 48].

Several diseases, e.g., lung cancer [49], HIV [50], and inflammatory bowel disease [51], are also influenced by oxidative stress induced by ROS generation. Further study is required to conceptualize the biochemical process of the generation and physiological interpretation of these compounds [2, 52]. Such hydrocarbons are stable end products of lipid peroxidation [2, 6, 45]. They are less soluble in blood and are hence released into the breath quickly after their formation in tissues. Thus, exhaled ethane and n-pentane concentrations have potential in the monitoring of oxidative stress in the body [45, 53, 54].

Elevated levels of ethane have been reported for patients with asthma, chronic obstructive pulmonary diseases (COPD), and cystic fibrosis [55-57]. Pentane has also been observed at increased levels in asthma patients [40, 58]. The concentrations of ethane and pentane are flow-dependent in asthmatic subjects [40].

\subsubsection{Unsaturated Hydrocarbons}

Isoprene (2-methyl-1,3-butadiene) is the major hydrocarbon found in human exhaled breath [59, 60]. It is thought to be formed following the mevalonic acid (MVA) pathway (Fig. 3) of cholesterol biosynthesis [2, 40, 61-64]. The formation of mevalonate from acetic acid is a crucial chemical reaction in the cholesterol biosynthesis. The compound 3-hydroxy-3-methyl-glutaryl coenzyme A (HMGCoA) catalyzes the rate-limiting step of sterol synthesis. Next, mevalonate is converted in the cytosol to isopentenyl pyrophosphate, followed by isomerization to dimethylallyl pyrophosphate (DMPP) [65]. After passing through the formation of intermediate carbonium ion, DMPP is rapidly converted to isoprene via an acid-catalyzed elimination reaction [2, 66]. It has been reported that breath isoprene levels can be decreased in humans by administration of $\mathrm{HMGCoA}$ reductase inhibitors, which block the enzyme responsible for the production of MVA during cholesterol biosynthesis [2].

The 1-deoxy-D-xylulose-4-phosphate/2-C-methylerythritol 5-phosphate (DOXP/MEP) pathway is regarded as another pathway of isoprene generation in plants and most bacteria. In plants and bacteria, the enzyme isoprene synthase converts DMPP into isoprene [63]. The MVA pathway is mainly present in higher eukaryotes [67]. A small fraction of exhaled isoprene may be of bacterial origin [68]. However, the exact origins have not been found $[66,69]$; further study on the origin of isoprene in the human body is needed. 
Fig. 2 Possible reactions and their products in free-radicalmediated lipid peroxidation [2]
PUFA

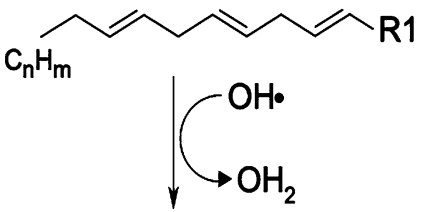

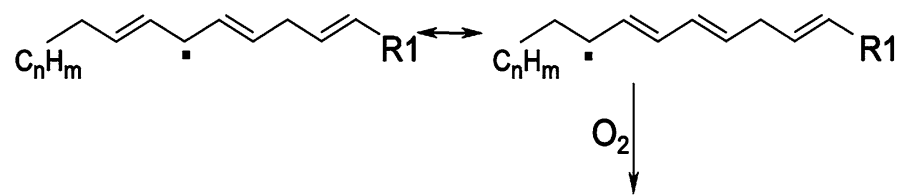

Conjugated Diene

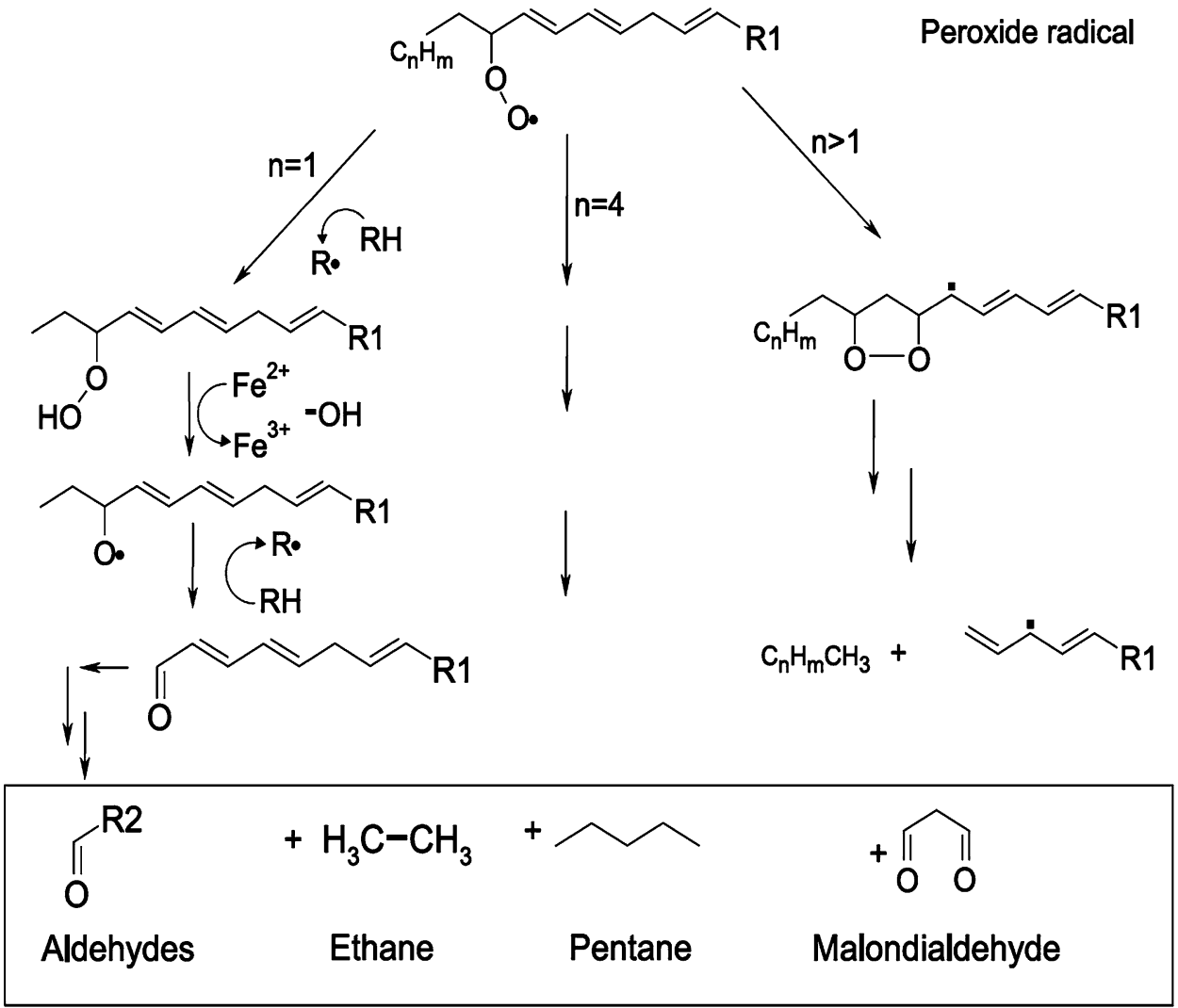

Isoprene levels have been found to be decreased in patients with acute respiratory distress syndrome [70], cystic fibrosis [71], and asthma [40]. The concentration of isoprene in breath appears to be age-dependent. Nelson et al. [72] found that children show significantly low concentrations of breath isoprene. It has also been reported that isoprene levels in breath are increased during physical activity. Isoprene, stored in muscles, gets released during muscle contraction (i.e., it is exercise-induced) [64, 73]. The change in breath isoprene concentration can also be contributed to the alteration of diffusion capabilities of peripheral tissue [64]. Increased production of breath isoprene has been observed in human subjects and animals with chronic kidney disease (CKD). In CKD animals, elevation of isoprene levels is associated with a significant increase in serum cholesterol level [62]. Breath isoprene levels are also altered by physiological and pathophysiological states (including hemodialysis, general anesthesia, liver disease, and cancer [74, 75]).

\subsection{Sulfur-Containing Compounds}

It has been reported that sulfur-containing compounds in the human body originate from the incomplete metabolism of methionine via the transamination pathway [2]. Such compounds, e.g., dimethyl sulfide, dimethyldisulfide, and ethyl mercaptane, manifest as a distinctive odor in cirrhotic patients' breath [76-78]. Sulfur compounds are suggested as major markers of liver failure [2]. The breath of patients with hepatocellular failure may have a sweet, musty, or 


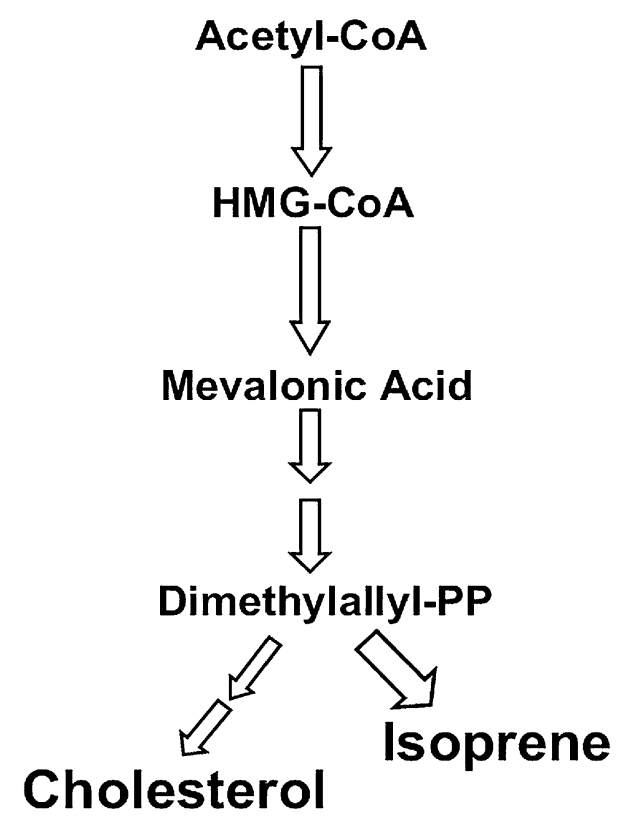

Fig. 3 Metabolic pathway of cholesterol synthesis and isoprene generation [61]

slightly fecal aroma, termed fetor hepaticus, which is mostly attributed to sulfur compounds. Dimethyl sulfide is regarded as an important metabolite for fetor hepaticus [79]. Impairment of liver function increases the level of these compounds, which have a characteristic smell, such as that of rotten cabbage [77, 80]. Bacteria and fungi related to lung infection (e.g., Haemophilus influenza, Streptococcus pneumoniae) also generate dimethyl sulfide [81]. Normally, human blood and breath shows very low (few parts per billion) concentrations of sulfur-containing compounds [5].

\subsection{Nitrogen-Containing Compounds}

Identification and quantification of amines in human breath has been reported since 1977. Patients with chronic renal failure have been reported to exhibit characteristic uremic breath odor, which is termed 'ammoniacal', 'fishy', or 'fetid'. Using GC, the presence of nitrogen-containing compounds (e.g., dimethylamine and trimethylamine at elevated concentration levels) contributing to the odor of uremic breath was established [82].

Ammonia is the major nitrogen-containing volatile biomarker. It originates in the body as a breakdown product of proteins. A substantial amount of these proteins comes from the bacterial degradation of proteins in the intestine. In the liver, ammonia is converted to urea and released in urine. Some of the ammonia is also released through the breath and the skin. Increased levels of ammonia have been observed in the blood when the liver fails to convert ammonia to urea. This may happen in subjects with cirrhosis or severe hepatitis [83].

Breath ammonia concentration is also influenced by cigarette smoking [84]. A relatively high concentration range [245-2935 ppb] of breath ammonia has been reported in normal healthy humans [83]. Such elevated levels may also be related to bacterial production in the oral cavity [5].

In the context of disease diagnosis using breath VOCs, several factors should be taken into consideration. The biology underlying both health and pathology is a complicated, non-linear, and dynamic process [85]. Human breath includes a complex composition. Food products, inhaled air composition, and volatiles that originate from normal and disease-related metabolic processes influence breath VOC content [23, 28, 86, 87]. For example, genomic and structural changes in the lung epithelium can alter the VOC concentration developed in normal physiological processes [88, 89]. Environmental sources [e.g., diet and inhaled (polluted) air] contribute a major part of exhaled breath VOCs [90]. For a breath test for disease identification, VOCs from systemic origin should be emphasized and exogenous VOCs should be excluded. However, exogenous breath VOCs may undergo physiochemical changes before exhalation [91]. Bacteria present in the lungs, gut, and oral cavity in animals and humans are potential VOC producers $[92,93]$. Thus, VOCs of microbial origin in the human body cannot be overlooked and may be utilized in disease diagnosis.

A large number of VOCs have been found in human breath. Although many of them have been reported to be biomarkers of several diseases, their exact physiological interpretation, including their biochemical status both in diseased and healthy conditions of the subjects, needs further study. It should be noted that the concentration ranges of breath VOCs for diseased persons and normal healthy subjects are not similar. For example, some exhaled breath VOCs and their concentration ranges in normal healthy subjects and lung cancer patients are given in Table 1.

\section{Underlying Principle in Exhaled Breath Analysis}

The underlying principle of breath analysis is based on the relatively rapid equilibrium between alveolar air and pulmonary capillary blood [94]. Following Henry's law, it can be stated that the quantity of a given substance released through the lungs varies in proportion to its vapor pressure [95]. Due to the rapid gas exchange at the blood-gas interface in the lungs, the gaseous compounds present in expired breath are directly proportional to their blood 
Table 1 Various breath VOCs and their concentrations in healthy normal subjects and lung cancer patients

\begin{tabular}{|c|c|c|c|}
\hline \multirow[t]{2}{*}{ Sl. no. } & \multirow[t]{2}{*}{ VOC } & \multicolumn{2}{|c|}{ Concentration (range/median/mean) ${ }^{\mathrm{a}}$ values (ppb) } \\
\hline & & Normal healthy subjects & Lung cancer patients \\
\hline 1 & Isoprene $[3,10,15,16,208]$ & $12.71[209]$ to $227[210]$ & $80-225.6[208]$ \\
\hline 2 & Acetone $[3,15,16,199,211-213]$ & $44[199]$ to $2744[83]$ & $150-870[131]$ \\
\hline 3 & 2-Pentanone $[15,199]$ & $1.80-4.11[199]$ & $3.25-8.77[199]$ \\
\hline 4 & Ethylbenzene $[3,15,16,199,208,213,214]$ & $0.28[208]$ to $18.38[199]$ & $1.45-3.16[199]$ \\
\hline 5 & Xylenes & $0.54-1.43[208]$ & $1.1-2.76[208]$ \\
\hline 6 & Toluene [199, 208, 211-213] & $1.45-37.21[199]$ & - \\
\hline 7 & Ethane $[15,215]$ & 0.51-1.02 (non-smokers) [216] & - \\
\hline 8 & Pentane & $6.84-14.36$ [199] & $1.73[199]$ to $28.3[208]$ \\
\hline 9 & Propane [212-214] & $3.71-19.98[212]$ & - \\
\hline 10 & Ethanol $[2,15,16,211-213,215]$ & $27[217]$ to $216.1[218]$ & $64-2160[131]$ \\
\hline 11 & Methanol $[2,16,213]$ & $33.05-216.1[218]$ & $63-110[131]$ \\
\hline 12 & Undecane $[15,16]$ & $0-4.83[219]$ & - \\
\hline 13 & Nonanal $[15,16,220,221]$ & $0.18[220]$ to $2.44[221]$ & $0.8[220]$ to $12.61[221]$ \\
\hline 14 & Benzene $[3,15,16,199,208,213,215]$ & $0.7[208]$ to $14.97[199]$ & $1.29-3.82[199]$ \\
\hline 15 & Heptane $[3,15,16,208,215]$ & $0.13-0.39[208]$ & $0.04-0.86[208]$ \\
\hline 16 & 2-Methylpentane $[15,16,199,208,213,215]$ & $0.08[208]$ to $10.80[199]$ & $0.93[199]$ to $7.6[208]$ \\
\hline 17 & Butanal $[199,211,215,220,221]$ & $0.18[220]$ to $72.2[211]$ & $0.48[220]$ to $131.4[211]$ \\
\hline 18 & Acetonitrile [199, 211-213] & $5.99-28.98$ [199] & $10.96-23.60[199]$ \\
\hline 19 & Butane $[16,211-213]$ & $3.6-14.8[211]$ & $3.3-9.2[211]$ \\
\hline 20 & 2-Propanol (isopropanol) $[15,16,199,213]$ & $3.21[199]$ to $94.1[13]$ & $84.2-340.7[211]$ \\
\hline 21 & 3-Methylpentane [15, 16, 199, 212, 213] & $1.05-8.76[199]$ & $0.94-8.87[199]$ \\
\hline 22 & Hexane $[15,16,199,211-213]$ & $0.29-12.86[212]$ & $1.44-1.88[199]$ \\
\hline 23 & Styrene $[16,208,213]$ & $0.14-0.55[208]$ & $0.22-0.95[208]$ \\
\hline 24 & Octane $[15,16,208,213]$ & $0.1-1.29[208]$ & $0.57-2.87[208]$ \\
\hline 25 & Decane $[15,16,208,213]$ & $0.36-10.3[208]$ & $7.1-33.6[208]$ \\
\hline 26 & 1,2,4-Trimethylbenzene $[15,16,208]$ & $0.12-0.28[208]$ & $0.24-0.56[208]$ \\
\hline 27 & Hexanal $[15,220]$ & $0.18-0.35[220]$ & $0.68-1.47[220]$ \\
\hline 28 & Pentanal $[15,220]$ & $0.11-0.37[220]$ & $0.32-1.08[220]$ \\
\hline 29 & Methanethiol [212] & $1.83-2.87[212]$ & - \\
\hline 30 & Dimethyl sulfide $[211,212]$ & $6.9-7.9[211]$ & $0-6.9[211]$ \\
\hline 31 & 2-Methyl-1,3-butadiene & 96.4 (median) [211] & 132.7 (median) [211] \\
\hline 32 & 1-Butanol [222] & 0.75 (median) [222] & - \\
\hline
\end{tabular}

${ }^{a}$ Data in other units (e.g., nmol/l, $\mu \mathrm{g} / \mathrm{l}$, etc.) are converted to equivalent ppb unit, considering breath temperature at $310^{\circ} \mathrm{K}$ and following the conversation formula applied in Ref. [212]

concentrations. However, no specialized transport system has been reported for the excretion of lethal gaseous substances by the lungs; such substances seem to be eliminated by the process of simple diffusion [94, 95]. Also, the elimination of gaseous substances is inversely proportional to their absorption by the lungs [95]. This mechanism holds true for any gas or vapor with no special affinity for certain blood components. During inhalation, gas molecules diffuse from the alveolar space into the blood and become dissolved. The uptake of gas molecules by tissues utilizes a simple physical dissolution process, facilitating the partition of these molecules between the air and blood during absorption and between blood and other tissues during distribution.

Any chemical substance in the alveoli stays there sufficiently long to reach a state of equilibrium with the blood. However, due to continuous contact of the inspired with blood, the state of equilibrium occurs rapidly. The ratio of the concentration of the chemical in the blood to that in the gas phase is constant at this equilibrium, termed the bloodgas partition coefficient $(K)$, and is unique for every gas [95]. 
Due to the simple mechanism described above, the VOCs in breath can be an excellent indicator of the levels of these compounds in blood [94]. However, the biomonitoring and interpretation of VOCs in breath also requires special attention to factors that can influence pulmonary excretion. Such factors include metabolism, breathing technique, diffusion-adsorption-desorption, ventilationperfusion, temperature, blood composition, and time [96].

\subsection{Significance of VOC Analysis in Human Breath Analysis and Applications}

Regarding clinical prospects, breath samples have application in the following major areas:

1. Clinical diagnosis Here, the aim is to analyze VOCs produced in the organism and released through expired or exhaled breath.

2. Exposure analysis Here, the aim is to obtain quick and accurate information concerning the levels of highly toxic exogenous VOCs that reach the blood stream.

Clinical diagnosis, being a noninvasive and quick approach, has achieved a scientific research interest in the field of medical science and technology [1, 2, 97-100]. Exposure assessment is mainly used for detecting noxious substances in indoor environments, which is outside of the scope of the present review.

The determination of VOCs in breath samples can provide clinically significant information for the diagnosis of diseases and biochemical processes involved. Elevated levels of ethane and pentane have been reported as markers of oxidative stress in subjects with heart transplant rejection [1, 2, 101], breast cancer, bronchial asthma [1, 101], asthma, COPD, obstructive sleep apnea, acute respiratory distress syndrome (ARDS), and mental and physical stress $[2,101]$. Methylated alkanes have also been proposed as markers of oxidative stress [1, 101]. Increased concentrations of exhaled n-alkanes have been observed following reperfusion of cardiopulmonary bypass [102] and in subjects with abdominal ischemia [103], ischemic liver [104], myocardial infarction [105], and ischemic heart disease [106]. Sepsis, or systemic inflammatory response syndrome, patients exhale significantly more pentane compared to that exhaled by healthy subjects [70]. Although few studies have found propane and butane (resulting from protein oxidation and fecal flora) to be biomarkers of lipid peroxidation [2], a recent study [42] claimed that patients with schizophrenia and bipolar disorder exhibit significantly increased levels of breath ethane and butane. Reduced isoprene levels have been found in patients with chronic heart failure [107] and ARDS [108]. Clinical studies demonstrated that isoprene may serve as a marker of cellular damage and repair. Increased concentration of isoprene has been reported in breath after smoking [109]. Several studies found elevated isoprene breath concentrations during and after hemodialysis [110]. Relatively higher concentrations of sulfur-containing compounds have been reported in liver transplant patients [111] and patients with liver disease [112]. The expired breath of cirrhotic patients includes ethyl mercaptane, dimethyl sulfide, or dimethyl disulfide, which are sulfur-containing compounds. Impairment of liver function also increases the level of sulfur-containing compounds [2, 101]. Helicobacter $(H$.$) pylori infection can be detected using the$ urea breath test $[1,101]$. Elevated levels of acetone in the expired breath of diabetes mellitus patients have been reported $[2,113]$. The VOCs of cystic fibrosis and breast, colon, and prostate cancer patients have been detected in some recent studies [3,101]. It has also been reported that a combination of more than 20 breath VOCs, predominantly alkanes, alkane derivatives, o-toluidine, aniline, and benzene derivatives, along with altered lipid peroxidation activity [1, 101], are able to distinguish patients with lung cancer at a probability level of about $70 \%$. Elevated levels of ammonia have been observed in the expired breath of patients with uremia, end stage renal failure [83, 84], acute liver failure, and hepatic encephalopathy [114-116]. Breath ammonia is also influenced by infection by $H$. pylori [114], which disturbs cerebral function [115] and produces symptoms of Alzheimer's disease [116].

The breath test was applied by Humphreys et al. [117] to the diagnosis of pneumonia associated with invasive mechanical ventilation. Similar studies on pneumonia diagnosis have been carried out by Hockstein et al. [118] and Hanson et al. [119] with satisfactory outcomes. In a study on 60 asthma patients (21 fixed asthma patients and 39 classic asthma patients) and 40 COPD patients, Fens et al. [120] discriminated fixed asthma patients from COPD patients and classic asthma patients, respectively. Remarkable results were also reported by Fens et al. [121] when they compared the exhaled VOCs from 20 asthma patients, 30 COPD patients, 20 non-smoker controls, and 20 smoker controls. Another research group [122] analyzed the exhaled air from 10 controls and 18 COPD patients. All the COPD patients and 8 of the 10 controls were reported to be correctly identified. Dragonieri et al. [123] discriminated 10 asthma patients from 10 healthy subjects. Similar results were obtained by Montuschi et al. [124], who recruited 27 asthma patients and 24 healthy subjects. The breath test has also been utilized to diagnose other respiratory diseases, including tuberculosis [125-127] and apnea [128-130]. Machado et al. [131] compared the exhaled breath VOCs of 14 lung cancer patients with 54 control patients. In another study, Dragonieri et al. [132] compared the VOCs present in the breaths of 10 lung cancer patients with those of 10 healthy controls and 10 
COPD patients, and found significant differences between the groups. Natale et al. [133] and Chen et al. [134] also performed breath tests to characterize lung cancer patients.

From the above discussion, it is undeniable that the analysis of VOCs in exhaled breath has potential for clinical diagnosis. However, the breath test has some shortcomings. The advantages and limitations of the breath test are listed in Table 2.

\section{Analytical Techniques Applied in Exhaled Breath VOC Analysis}

Several techniques have been tailored and employed to monitor and analyze the VOCs present in human exhaled breath. Technologies used in the breath test are described below.

It should be noted that there are some potential obstacles in breath gas analysis. These include low concentrations of exhaled breath VOCs, lack of proper sampling and measuring techniques, and high humidity of breath gas [10]. The majority of breath VOCs have nanomolar $\left(10^{-9}\right)$ and picomolar $\left(10^{-12}\right)$ concentration ranges and require highly sensitive devices and sophisticated analytical methods for their proper identification [13]. Modern sampling and analytical methods have solved these problems to some extent.

The analysis of VOCs in exhaled breath requires some advanced technology that may pacify the analysis process and provide reliable interpretation of the obtained data. In this regard, incorporating sensors and sensor arrays might be useful in the analysis of expired breath VOCs of diabetes patients.

\subsection{Gas Chromatography and Gas Chromatography-Mass Spectrometry}

Commonly used methods for the analysis of exhaled breath VOCs are GC, GC-MS, and GC with tandem MS (GC$\mathrm{MS}^{2}$ ) [4, 7, 61, 98]. In practice, GC/MS systems are often associated with other methods, e.g., solid-phase extraction (SPE) and solid-phase microextraction (SPME), for the analysis of breath VOCs [1]. In breath analysis, GC-MS employs the electron impact ionization technique. The unique fragmentation pattern of each analyte molecule is used for its identification, which is done using chromatographic retention data and mass spectral data using spectral libraries [98]. GC-MS has high reproducibility, high sensitivity, and robustness [135] and conveys potential information of biological mechanisms relevant to respective VOCs [136, 137].

Combined with a preconcentration system, these methods can be effectively applied to the off-line collection, separation, and identification of the majority of compounds (e.g., aliphatics, alcohols, aldehydes, ketones, amines, and halogenated compounds) in human breath [4, 7, 98]. GC and GC-MS have numerous applications in clinical studies $[2,138]$. These systems are sufficiently sensitive to quantify breath gases of very low concentration (parts per billion/ppb/ppbv—parts per trillion/ppt/pptv) levels $[139,140]$.

However, despite their high sensitivity, GC-MS and related methods have poor portability and are time-consuming, costly, difficult to handle, and not suited for realtime and repeated measurements [10]. Therefore, GC-MS is used especially when the aim is to identify VOCs in pathophysiological discovery, even though it can also be clinically incorporated in larger hospitals when logistics allow samples to be directly analyzed.

\subsection{Proton-Transfer Reaction-Mass Spectrometry}

Compared to GC-MS, proton-transfer reaction-mass spectrometry (PTR-MS) is more sensitive in detecting VOC concentrations, down to ppt [13] and ppb levels [7, 61, 141], quickly and accurately and does not require the time-consuming preconcentration step [13]. In PTRMS, analytes are characterized as per their mass-to-charge $(\mathrm{m} / \mathrm{z})$ ratio only. PTR-MS includes an ion source and a drift tube (ion-transfer region) coupled to an MS detector. $\mathrm{H}_{3} \mathrm{O}^{+}$ ions generated in the ion source region are mixed with an air sample continuously flowing at the top of the drift tube and proton transfer takes place as the gas sample passes through the drift tube [142].

PTR-MS has been used for monitoring anesthetic agents [143], breath profiling [144], and studying the effects of
Table 2 Advantages and limitations of exhaled breath test

\begin{tabular}{ll}
\hline Advantages & Limitations \\
\hline Noninvasive & Extraneous parameters, e.g., diet, environment \\
Repeated measurements allowed & Lack of standardization in breath collection \\
Possibly portable & Lack of standardization in analytical techniques \\
Real-time monitoring possible & Wide variability in results \\
Quick measurements possible & Storage of samples \\
Personalized medicine (breath print) & Physician acceptance \\
\hline
\end{tabular}


hemodialysis [145]. This technique is also suited for online and multiple measurements. However, PTR-MS systems cannot differentiate between substances that have the same molecular mass [13]. Chemical identification of the analytes thus cannot be performed using this technique. For this purpose, other techniques should be used $[7,10]$.

\subsection{Selected Ion Flow Tube-Mass Spectrometry}

Similar to PTR-MS, selected ion flow tube-mass spectrometry (SIFT-MS) shows quick performance in quantifying exhaled breath analytes [4, 7, 61]. SIFT-MS employs a chemical ionization technique using positive precursor ions $\left(\mathrm{H}_{3} \mathrm{O}^{+}, \mathrm{NO}^{+}\right.$, or $\left.\mathrm{O}_{2}^{+}\right)$generated in an ion source. The ion-molecule reactions in SIFT-MS generate characteristic product ions corresponding to each trace gas species present in the sample. These product ions are mass-sorted and counted by a downstream detection system. SIFT-MS has been applied to polar substances (e.g., acetone, ammonia, acetaldehyde, and alcohols) and unsaturated hydrocarbons (e.g., isoprene) [98].

SIFT-MS is a potential real-time quantification tool for several breath gases [4, 61, 146-148]. It can detect several VOCs with concentrations at ppt/pptv and $\mathrm{ppb} / \mathrm{ppbv}$ levels [7, 61, 98]. SIFT-MS outperforms GC-MS in terms of the identification and analysis of small molecules [149]. For a specified mass range, a large number of target compounds can be detected and monitored simultaneously.

\subsection{Sensor Arrays and Electronic Noses}

Sensor technology has been utilized in several clinical tests (e.g., blood gas analysis) for many years [98]. Sensor systems are characterized by their high throughput, ease of use, and affordability [150]. With the aid of modern fabrication techniques, sensor arrays find their notable implementations in optimizing the conditions for clinical applications. One of the major sensor-based techniques in the clinical domain is the electronic nose (e-nose), which incorporates a series of non-selective gas sensors and a pattern-recognition algorithm $[4,150,151]$. The pattern of volatile compounds may represent not only an infecting organism or a disease state but also the metabolism of the host response, as well as other associated conditions [97, 152].

An e-nose, resembling the human (or animal) nose, can recognize the 'smell-print' to which it is trained [7, 61]. Utilizing nanosensor arrays, an e-nose detects patterns in complex mixtures of exhaled breath VOCs. Such patterns may serve as potential indicators of certain disease conditions $[7,97,121,131,152]$ and can pacify the clinical diagnosis process. E-noses have been used for detecting pathogens present in bacterial cultures [1, 153] and determining halitosis [1], uremia [154], renal disease, airway inflammation [1, 155], cancer $[1,3,13,132,156]$, malignant pleural mesothelioma [157], and pulmonary diseases [1, 120, 121, 127, 132].

\subsection{Ion-Mobility Spectrometry}

Ion-mobility spectrometry (IMS) is a fast technique that can detect volatile compounds of very low concentrations (ppm-ppb) without any preconcentration [7, 98]. It is based on estimating the time taken for an ion to travel through a drift tube. Variations in the humidity of an exhaled breath sample may influence the ion-drift time [7]. IMS can separate and identify different substances under ambient air conditions. IMS can be coupled with GC [158] or MS [159] for unequivocal identification of substances.

IMS measures disease-specific combinations of VOCs, and characterizes the mixture using a pattern recognition algorithm to aid clinical diagnosis. Wide application of hand-held IMS units has been reported in military applications [160]. IMS has been used to identify some metabolites [161] and bacteria in human breath [162]. Unfortunately, IMS cannot identify unknown volatile compounds in a sample [161, 163].

\subsection{Optical Absorption}

Optical absorption can be employed to identify a disease once a specific molecule associated with the disease has been recognized. This method is very selective and can be used to perform on-line real-time analysis of a specific compound at the ppb level [7]. Chemiluminescence analyzers employed for measuring fractional concentrations of exhaled nitric oxide (FeNO analyzers) work on the principle of optical absorption. Such instruments are characterized by their high cost, large size, and poor portability. However, low-cost portable instruments based on the electrochemical cell technique have been recently developed [164].

Table 3 gives a brief summary of the applications, advantages, and disadvantages of analytical methods used in breath testing.

\section{Diabetes Mellitus and Breath Test}

\subsection{Diabetes}

Diabetes mellitus, one of the major diseases, poses a great threat to human health and has become a universal epidemic [165-167]. According to the World Health Organization (WHO), approximately 350 million people globally have diabetes, which is projected to be the 7th leading 
Table 3 Characteristics of various analytical techniques used for breath test [7, 61, 98]

\begin{tabular}{|c|c|c|c|c|}
\hline Analytical method & $\begin{array}{l}\text { Typical } \\
\text { compounds }\end{array}$ & $\begin{array}{l}\text { Limit of } \\
\text { detection }\end{array}$ & Advantages & Limitations \\
\hline GC-MS & $\begin{array}{l}\text { Sulfides, hydrocarbons, } \\
\text { aldehydes }\end{array}$ & $\begin{array}{l}\text { ppt-ppb } \\
\text { ppt-ppb } \\
\text { ppt-ppb }\end{array}$ & High selectivity and sensitivity & $\begin{array}{l}\text { Large sampling time/requires } \\
\text { standardization/requires } \\
\text { preconcentration }\end{array}$ \\
\hline PTR-MS & $\begin{array}{l}\text { Aromatic } \\
\text { compounds, } \\
\text { isoprene }\end{array}$ & $\begin{array}{l}\mathrm{ppt} \\
\mathrm{ppt}\end{array}$ & Analysis is real-time & $\begin{array}{l}\text { Small range of detectable } \\
\text { compounds/compounds } \\
\text { cannot be identified }\end{array}$ \\
\hline SIFT-MS & Ethanol, ammonia & $\begin{array}{l}\text { ppt-ppb } \\
\text { ppt-ppb }\end{array}$ & $\begin{array}{l}\text { Analysis is real-time/wide } \\
\text { range of detection }\end{array}$ & $\begin{array}{l}\text { Compounds cannot be } \\
\text { identified }\end{array}$ \\
\hline $\begin{array}{l}\text { Sensor arrays/e- } \\
\text { noses }\end{array}$ & Various VOCs & N/A & $\begin{array}{l}\text { Analysis is real-time/potential } \\
\text { for portability and miniaturization }\end{array}$ & $\begin{array}{l}\text { Pattern recognition makes } \\
\text { identification of compounds } \\
\text { impossible }\end{array}$ \\
\hline Ion mobility & $\begin{array}{l}\text { Isoprene, acetone, } \\
\text { ammonia }\end{array}$ & $\begin{array}{l}\text { ppt-ppb } \\
\text { ppt-ppb } \\
\text { ppt-ppb }\end{array}$ & $\begin{array}{l}\text { Vacuum systems are not } \\
\text { required and ambient air } \\
\text { can be used as a carrier gas }\end{array}$ & $\begin{array}{l}\text { Not very useful for identifying } \\
\text { unknown compounds in } \\
\text { multi-component mixtures }\end{array}$ \\
\hline Optical absorption & $\begin{array}{l}\text { Ethane, carbon } \\
\text { monoxide }\end{array}$ & $\begin{array}{l}\text { ppt } \\
\text { ppt }\end{array}$ & $\begin{array}{l}\text { Analysis is real-time/potential } \\
\text { for portability and miniaturization }\end{array}$ & $\begin{array}{l}\text { Limited by available } \\
\text { technology to } \\
\text { meet sufficient specificity/ } \\
\text { selectivity } \\
\text { required for practical use }\end{array}$ \\
\hline
\end{tabular}

cause of death in the year 2030 [166, 168, 169]. Diabetes also refers to a variable and complicated disease condition that can severely affect almost every organ in the human body. This disease may be considered as a combination of several diseases with versatile origins, various ages of onset, and multiple treatment requirements [167].

Diabetes manifests itself as an uncommon combination of dramatic symptoms and has a lethal outcome [170]. It is a common metabolic disorder characterized by chronic hyperglycemia that can be potentially lifethreatening. Improper management of this deadly disease may lead to damage of the eyes, kidneys, heart, and nerves [166, 171].

\subsection{Classification of Diabetes}

WHO classifies diabetes into type 1 diabetes (insulin-dependent diabetes mellitus) and type 2 diabetes (non-insulin-dependent diabetes mellitus). Type 1 diabetes stems from an absolute insulin deficiency. Usually, it is an autoimmune disease and can lead to the destruction of the insulin-secreting beta cells in the pancreas. However, the origin of the destruction of beta cells is unknown in some cases. Type 2 diabetes results from a relative insulin deficiency that may be associated with varying degrees of insulin action defects, known collectively as insulin resistance [167]. It spreads in the body much more slowly than does type 1 and does not make people sick as fast. When it victimizes people, it can appear to be formidable one [116, 117].
Diabetes mellitus can appear in forms other than type 1 and type 2. It can also originate from gene mutations, pancreatic damage, and excessive hormone production. Diabetes can also be induced by medications. For example, Niacin is used to lower triglyceride levels and raise HDL cholesterol levels. Niacin lowers insulin effectiveness and can cause an increase in blood glucose levels (BGLs) [172]. Gestational diabetes mellitus (GDM) is another form of diabetes [172, 173]. It can develop when a pregnant woman has limited beta cell capacity and cannot respond to the additional insulin demand. An oral glucose tolerance test is the general approach for GDM screening. A recent study used breath gas analysis using PTR-MS for screening GDM [173].

\section{Breath Analysis for Diabetes Mellitus and Available Techniques}

The management of any disease requires its timely and regular diagnosis. The traditional method for diagnosing or monitoring diabetes is collecting blood samples from patients to check whether their BGL falls within the normal range. This method is accurate but painful, invasive, inconvenient, and impractical and may be expensive [12, 174-176].

In addition, the measurement of plasma insulin has clinical importance for monitoring the progression of type 2 diabetes, discriminating common states (where components of both type 1 and type 2 diabetes are present 
simultaneously), and assessing and screening prediabetic states $[174,176]$. Also, monitoring insulin is helpful in investigating aspects of metabolism. Insulin regulates glucose disposal and also exerts a strong antilipolytic effect that is reduced significantly in patients with insulin resistance $[174,177]$. However, tests for insulin concentration and sensitivity are very laborious. Tests for circulating lipids are important for diabetic patients as hyperlipidemia is a critical risk factor for heart disease. As lipids enhance ketone body formation, any change in their levels may also be related to changes in insulin or glucose metabolism [174, 178]. Detailed knowledge and information of the interplay of these metabolic variables and their pathways may give clinical professionals insight into their patients' health and hygiene, and reliable noninvasive monitoring, which would improve both the diagnosis and treatment of diabetes.

Researchers have thus focused on noninvasive methods for screening diabetes and predicting BGL. Such methods include bioimpedance spectroscopy, fluorescence technology, and iontophoresis [179, 180]. However, these methods suffer from a lack of specificity and inaccuracy due to subject movement and sweating, skin irritation, etc. $[165,179,180]$. Despite the number of studies carried out, no FDA-approved commercial device for screening diabetes and predicting BGL exists [181].

An emerging and promising noninvasive approach for diagnosing diabetes is the breath test. Exhaled breath consists of a large number of various gaseous VOCs. These VOCs may be used as noninvasive biomarkers of a number of diseases, including diabetes. It has been reported that concentrations of several breath biomarkers in diabetics show significant differences from those for normal healthy subjects. Also, the concentrations of some biomarkers are correlated with the BGLs of diabetics. Thus, it is possible both to screen diabetes and predict BGLs by analyzing the exhaled breath VOCs or breath biomarkers of diabetes patients. For clinical applications, breath analysis is a noninvasive approach. Analysis of breath biomarkers and their concentrations has great potential for detecting a disease, monitoring its progression, or monitoring therapy $[165,182]$.

Several investigations have been carried out to study the breath biomarkers of diabetes. Acetone and other VOCs $[165,183-187]$ in breath have been shown either to have abnormal concentrations in diabetics compared to healthy controls or to correlate with the BGL. Compared to other noninvasive approaches for diabetes management, breath analysis is more advantageous and readily acceptable and it is easier to collect samples for it [174], making it an attractive and effective method for noninvasive diabetes screening and BGL prediction $[174,175]$.

\section{Physiological Aspects of Diabetes Mellitus Related to Breath Test}

The diagnosis, screening, or monitoring of a disease using the breath test is not a simple task. Implementation of breath test for detecting a disease and accurate interpretation of the measured data not only require details of the pathophysiological background and systemic metabolism underlying the particular disease condition of the subject but also an elaborate understanding of the same under normal healthy conditions. Additionally, the methodology and technology used for such a test affect conclusions regarding the disease. Characterization, interpretation, quantification, and analysis of VOCs found in breath for a diseased subject are of great importance as those of for a healthy person for a significant statistical interpretation of the obtained data.

An accurate breath test for diabetes mellitus needs the proper realization of the changes of pathophysiological mechanisms and systemic metabolism induced by the disease. Such changes may be useful for the diagnosis of diabetes [174]. The following discussion highlights the changes in the lungs and systemic metabolism in diabetics.

\subsection{Lungs}

It is believed that both the pulmonary vasculature and lung function are affected by diabetes, which deteriorates the gas exchange kinetics of several VOCs. This should be taken into consideration when incorporating VOCs in the breath test for diabetes. Further progress of the disease imparts severe pathological changes, which would require frequent recalibration or prevent specific VOCs from being used in the breath test. It should be noted here that although the underlying pathophysiological mechanisms are not fully understood, several studies have investigated such mechanisms in diabetics.

It has been reported that there is a correlation between diabetes (both types) and mild restrictive lung disease and micropathology-induced declined diffusion capacity. Such micropathology originates from non-enzymatic glycation and results in stiffening of the lung tissues [174, 188]. Thicker epithelial and endothelial capillary basal laminae have been found in diabetes patients after autopsies $[174,189]$. Diabetic subjects also manifest elevated levels of plasma myeloperoxidase (which produces damaging oxidative species) and $\alpha$-defensins (which promote atherosclerosis and lung injury) [155, 174, 190-192] and have increased risk of ROS production, pulmonary hypertension (type 2 patients), and enhanced pro-sclerotic and pro-fibrotic growth factors [174, 193, 194]. 


\subsection{Systemic Metabolism}

The breath composition of diabetic subjects is changed due to the metabolic activities involved with the disease. Altered BGLs affect the breath VOC concentrations. Glucose may also indirectly affect other VOC levels. This can be exemplified by a variation in the rate of acetone formation due to hyperglycemia, induced by the associated suppressive effect of physiological compensatory hyperinsulinemia, which at its elevated stage characterizes type 2 diabetes and suppresses lipolysis [174, 177]. Exhaled breath isoprene also changes due to alteration in cholesterol biosynthesis $[74,174]$. Thus, the variation in concentrations of ketones and other VOCs may be manifestations of the changing metabolism of glucose and insulin.

\section{Relating Breath VOCs to Diabetes Mellitus}

Several studies have been carried out to investigate exhaled breath VOCs related to diabetes mellitus. Breath analysis of diabetic subjects can provide information about their BGLs. Exhaled acetone has been reported to be an important biomarker of diabetes [195]. Since the 1960s, a

Table 4 VOCs found in breath of diabetes patients and healthy normal subjects

\begin{tabular}{|c|c|c|c|c|c|}
\hline \multirow[t]{2}{*}{ Sl. no. } & \multirow[t]{2}{*}{ VOC } & \multirow{2}{*}{$\begin{array}{l}\text { Type of } \\
\text { diabetes }\end{array}$} & \multirow[t]{2}{*}{ Applied method } & \multicolumn{2}{|c|}{ Concentration $(\mathrm{ppb})(\text { range/median } / \text { mean })^{\mathrm{a}}$} \\
\hline & & & & Normal healthy subjects & $\begin{array}{l}\text { Diabetes mellitus } \\
\text { patients }\end{array}$ \\
\hline 1 & $\begin{array}{l}\text { Acetone }[165,174,182, \\
\text { 200, 201, 214, } \\
\text { 223-226] }\end{array}$ & $\begin{array}{r}\text { Type } 1 \\
\text { Type } 1 \\
\text { and } 2 \\
\text { Type } 2\end{array}$ & $\begin{array}{l}\text { Gas chromatography [214] } \\
\text { Sensor-array-based method } \\
\text { [165] } \\
\text { Solid-phase micro extraction } \\
\text { GC-MS analysis [223] }\end{array}$ & $44[199]$ to $2744[83]$ & $\begin{array}{l}2200[200] \text { to } 21000 \\
[165,201] \text { (type } 1) \\
1760[165,183] \text { to } \\
9400[200] \text { (type } \\
\text { 2) }\end{array}$ \\
\hline 2 & Ethylbenzene [174, 214] & Type 1 & Gas chromatography [214] & $0.28[208]$ to 18.38 [199] & NA \\
\hline 3 & Xylene $[174,223]$ & Type 2 & $\begin{array}{l}\text { Solid-phase micro extraction } \\
\text { GC-MS analysis [223] }\end{array}$ & $0.54-1.43[208]$ & NA \\
\hline 4 & Toluene $[174,223]$ & Type 2 & $\begin{array}{l}\text { Solid-phase micro extraction } \\
\text { GC-MS analysis }[223]\end{array}$ & $1.45-37.21$ [199] & NA \\
\hline 5 & Ethane [174, 227] & $\begin{array}{r}\text { Type } 1 \\
\text { and } 2\end{array}$ & GC-MS analysis [227] & $0.51-1.02[216]$ & NA \\
\hline 6 & Pentane [174] & $\begin{array}{r}\text { Type } 1 \\
\text { Type } 1 \\
\text { and } 2\end{array}$ & $\begin{array}{l}\text { Gas chromatography [214] } \\
\text { GC-MS analysis [233] }\end{array}$ & $6.84-14.36$ [199] & NA \\
\hline 7 & Propane $[174,214]$ & Type 1 & Gas chromatography [214] & $3.71-19.98$ [212] & NA \\
\hline 8 & Isoprene [174] & Type 2 & GC-MS analysis [212] & $12.71[209]$ to 227 [210] & NA \\
\hline 9 & Ethanol $[174,214]$ & Type 1 & Gas chromatography [214] & 27 [217] to $216.1[218]$ & NA \\
\hline 10 & Methanol $[174,214]$ & Type 1 & Gas chromatography [214] & $33.05-216.1[218]$ & NA \\
\hline 11 & Isopropanol [223] & Type 2 & $\begin{array}{l}\text { Solid-phase micro extraction } \\
\text { GC-MS analysis }[223]\end{array}$ & $3.21[199]$ to $94.1[13]$ & NA \\
\hline 12 & $\begin{array}{l}\text { 2,3,4-Trimethylhexane } \\
\text { [223] }\end{array}$ & Type 2 & $\begin{array}{l}\text { Solid-phase micro extraction } \\
\text { GC-MS analysis [223] }\end{array}$ & NA & NA \\
\hline 13 & $\begin{array}{l}\text { 2,6,8-Trimethyldecane } \\
\text { [223] }\end{array}$ & Type 2 & $\begin{array}{l}\text { Solid-phase micro extraction } \\
\text { GC-MS analysis [223] }\end{array}$ & NA & NA \\
\hline 14 & Tridecane [223] & Type 2 & $\begin{array}{l}\text { Solid-phase micro extraction } \\
\text { GC-MS analysis [223] }\end{array}$ & NA & NA \\
\hline 15 & Undecane [223] & Type 2 & $\begin{array}{l}\text { Solid-phase micro extraction } \\
\text { GC-MS analysis [223] }\end{array}$ & $0-4.83[219]$ & NA \\
\hline
\end{tabular}

$N A$ not available in the literature

${ }^{\text {a }}$ Data in other units (e.g., nmol/l, $\mu \mathrm{g} / \mathrm{l}$, etc.) are converted to equivalent ppb unit, considering breath temperature at $310^{\circ} \mathrm{K}$ and following the conversation formula applied in Ref. [212] 
large number of studies have been conducted on the analysis of acetone in the expired breath of diabetics [195-197]. Breath acetone is linked to ketoacidosis $[174,198]$. Elevated levels of acetone in the blood and breath of diabetics are a key cause of the fruity or sweet smell of the subjects' expired breath [195]. Studies have also found a high correlation between BGL and the concentration of breath acetone [165, 185, 186, 195, 197, 198] in patients with diabetes. The exhaled breath acetone concentration has been reported to be in the range of $0.044 \mathrm{ppm}$ [199] to $2.744 \mathrm{ppm}$ [83] for normal healthy subjects, $2.2 \mathrm{ppm}$ [200] to $21 \mathrm{ppm}[165,201]$ for type 1 diabetes patients, and $1.76 \mathrm{ppm}[165,183]$ to $9.4 \mathrm{ppm}$ [200] for type 2 diabetes patients. The elevation of acetone level indicates either a deficit of insulin in cells or cells' inability to effectively utilize available insulin [28]. Breath acetone can thus serve as a potential noninvasive biomarker of diabetes $[28,195]$.

However, the determination of breath acetone concentration alone may not optimize the diagnosis of diabetes as this concentration is also affected by the degree of insulin resistance, diurnal fluctuations, lipolytic activity, diet nutrient composition, gender [174], body exercise [28], and fasting status [28, 174]. Studies have shown the presence of other breath VOCs in the diabetics' breath. A correlation between breath ethanol and BGL was reported by Galassetti et al. [195, 198]. Experiments on animals have also yielded interesting results. An elevated acetone level was found in obese mice after the application of a high-fat diet even after fasting [202]. Alteration in exhalation pattern and volatile metabolites was found during fasting and low-dose glucose treatment [203]. Hyperglycemia may influence medullary thyrotropin-releasing hormone stimulation of vagal outflow to the stomach [204].

Table 4 lists VOCs found in the exhaled breath of diabetes patients and normal healthy subjects. Few studies have reported the concentration ranges of breath VOCs, except for acetone, for diabetes mellitus patients.

\section{Conclusion}

This review paper reflects the research trends and developments of breath analysis in disease determination since 1966. The status of characteristic breath VOCs (mostly of systemic origin) at various physiological states was discussed. The advantages and limitations of breath tests and related analytical methods were highlighted. The application of breath VOC analysis to the diagnosis of diabetes mellitus was reviewed. 15 VOCs found in diabetics' breath were listed, along with a list of 50 VOCs and their concentration ranges for normal healthy persons. The concentration ranges of a few breath VOCs found in disease conditions (e.g., lung cancer) were also highlighted.

Despite the potential of breath tests for the clinical diagnosis of several diseases, such tests have some drawbacks. The major challenge limiting the application of breath analysis in the clinical domain is the lack of standardization in both breath collection [4, 5, 205] and analytical approaches $[4,205,206]$, which contribute to the wide variations of reported analytical results [5, 99, 182, 207]. Additionally, insight into the metabolic aspects and background physiology of breath VOCs and their exact contributions both to healthy and diseased states is required to justify their clinical importance from a diagnostic point of view. Breath tests are currently rarely used in clinical practice. However, it is expected that ongoing research and development in medical science and sensor-based analytical instrumentation in breathomics will establish breath analysis as a reliable approach for the detection and monitoring of various diseases.

Open Access This article is distributed under the terms of the Creative Commons Attribution 4.0 International License (http://crea tivecommons.org/licenses/by/4.0/), which permits unrestricted use, distribution, and reproduction in any medium, provided you give appropriate credit to the original author(s) and the source, provide a link to the Creative Commons license, and indicate if changes were made.

\section{References}

1. Francesco, F. D., Fuoco, R., Trivella, M. G., \& Ceccarini, A. (2005). Breath analysis: Trends in techniques and clinical applications. Microchemical Journal, 79, 405-410.

2. Miekisch, W., Schubert, J. K., \& Noeldge-Schomburg, G. F. E. (2004). Diagnostic potential of breath analysis-Focus on volatile organic compounds. Clinica Chimica Acta, 347, 25-39.

3. Dent, A. G., Sutedja, T. G., \& Zimmerman, P. V. (2013). Exhaled breath analysis for lung cancer. Journal of Thoracic Disease. doi:10.3978/j.issn.2072-1439.2013.08.44.

4. Kim, K. H., Jahan, S. A., \& Kabir, E. (2012). A review of breath analysis for diagnosis of human health. Trends in Analytical Chemistry, 33, 1-8.

5. Righettoni, M., Amann, A., \& Pratsinis, S. E. (2015). Breath analysis by nanostructured metal oxides as chemo-resistive gas sensors. Materials Today, 18(3), 163-171.

6. Mazzatenta, A., Giulio, C. D., \& Pokorski, M. (2013). Pathologies currently identified by exhaled biomarkers. Respiratory Physiology \& Neurobiology, 187(1), 128-134.

7. Dummer, J., Storer, M., Swanney, M., McEwan, M., ScottThomas, A., Bhandari, S., et al. (2011). Analysis of biogenic volatile organic compounds in human health and disease. Trends in Analytical Chemistry, 30(7), 960-967.

8. Phillips, M. (1992). Breath tests in medicine. Scientific American, 267(1), 74-79.

9. Risby, T. H. (2002). Volatile organic compounds as markers in normal and diseased states. In N. Marczin \& M. H. Yacoub (Eds.), Disease markers in exhaled breath (pp. 113-122). Amsterdam: IOS Press. 
10. Amann, A., Poupart, G., Telser, S., Ledochowski, M., Schmid, A., \& Mechtcheriakov, S. (2004). Applications of breath gas analysis in medicine. International Journal of Mass Spectrometry, 239, 227-233.

11. Harger, R. N., Lamb, E. B., \& Hulpieu, H. R. (1938). A rapid chemical test for intoxication employing breath-A new reagent for alcohol and a procedure for estimating the concentration of alcohol in the body from the ratio of alcohol to carbon dioxide in the breath. Journal of the American Medical Association, 110, 779-785.

12. Pauling, L., Robinson, A. B., Teranishi, R., \& Cary, P. (1971). Quantitative analysis of urine vapor and breath by gas-liquid partition chromatography. Proceedings of the National Academy of Sciences of the United States of America, 68(10), 2374-2376.

13. Wehinger, A., Schmid, A., Mechtcheriakov, S., Ledochowski, M., Grabmer, C., Gastl, G. A., et al. (2007). Lung cancer detection by proton transfer reaction mass-spectrometric analysis of human breath gas. International Journal of Mass Spectrometry, 265, 49-59.

14. Amann, A., \& Smith, D. (2005). Breath analysis for clinical diagnosis and therapeutic monitoring. Singapore: World Scientific Publishing Co., Pte. Ltd.

15. Phillips, M. (1997). Method for the collection and assay of volatile organic compounds in breath. Analytical Biochemistry, 247, 272-278.

16. Phillips, M., Herrera, J., Krishnan, S., Zain, M., Greenberg, J., \& Cataneo, R. N. (1999). Variation in volatile organic compounds in the breath of normal humans. Journal of Chromatography B, 729, 75-88.

17. Costello, B. D. L., Amann, A., Al-Kateb, H., Flynn, C., Filipiak, W., Khalid, T., et al. (2014). A review of the volatiles from the healthy human body. Journal of Breath Research. doi:10.1088/ 1752-7155/8/1/014001

18. Agapiou, A., Amann, A., Mochalski, P., Statheropoulos, M., \& Thomas, C. L. P. (2015). Trace detection of endogenous human volatile organic compounds for search, rescue and emergency applications. Trends in Analytical Chemistry, 66, 158-175.

19. Mazzone, P. J. (2008). Analysis of volatile organic compounds in the exhaled breath for the diagnosis of lung cancer. Journal of Thoracic Oncology, 3, 774-780.

20. Filipiak, W., Ruzsanyi, V., Mochalski, P., Filipiak, A., Bajtarevic, A., Ager, C., et al. (2012). Dependence of exhaled breath composition on exogenous factors, smoking habits and exposure to air pollutants. Journal of Breath Research. doi:10. 1088/1752-7155/6/3/036008.

21. Mochalski, P., King, J., Klieber, M., Unterkofler, K., Hinterhuber, H., Baumann, M., et al. (2013). Blood and breath levels of selected volatile organic compounds in healthy volunteers. Analyst, 138(7), 2134-2145.

22. Mochalski, P., King, J., Haas, M., Unterkofler, K., Amann, A., \& Mayer, G. (2014). Blood and breath profiles of volatile organic compounds in patients with end-stage renal disease. BMC Nephrology. doi:10.1186/1471-2369-15-43.

23. Amann, A., Costello, B. D. L., Miekisch, W., Schubert, J., Buszewski, B., Pleil, J., et al. (2014). The human volatilome: Volatile organic compounds (VOCs) in exhaled breath, skin emanations, urine, feces and saliva. Journal of Breath Research. doi:10.1088/1752-7155/8/3/034001.

24. Amann, A., Miekisch, W., Schubert, J., Buszewski, B., Ligor, T., Jezierski, T., et al. (2014). Analysis of exhaled breath for disease detection. Annual Review of Analytical Chemistry, 7, 455-482.

25. Phillips, M., Gleeson, K., Hughes, J. M. B., Greenberg, J., Cataneo, R. N., Baker, L., et al. (1999). Volatile organic compounds in breath as markers of lung cancer: A cross-sectional study. The Lancet, 353, 1930-1933.
26. King, J., Unterkofler, K., Teschl, G., Teschl, S., Koc, H., Hinterhuber, H., et al. (2011). A mathematical model for breath gas analysis of volatile organic compounds with special emphasis on acetone. Journal of Mathematical Biology, 63(5), 959-999.

27. Kalapos, M. P. (2003). On the mammalian acetone metabolism: From chemistry to clinical implications. Biochimica et Biophysica Acta (BBA)—General Subjects, 1621(2), 122-139.

28. Ye, M., Chien, P. J., Toma, K., Arakawa, T., \& Mitsubayashi, K. (2015). An acetone bio-sniffer (gas phase biosensor) enabling assessment of lipid metabolism from exhaled breath. Biosensors \& Bioelectronics, 73, 208-213.

29. Kalapos, M. P. (2014). Acetone. In P. Wexler (Ed.), Reference module in biomedical sciences, from encyclopedia of toxicology (3rd ed., pp. 36-39). London: Academic Press.

30. Ruzsanyi, V., Lederer, W., Seger, C., Calenic, B., Liedl, K. R., \& Amann, A. (2014). Non- ${ }^{13} \mathrm{CO}_{2}$ targeted breath tests: A feasibility study. Journal of Breath Research. doi:10.1088/17527155/8/4/046005.

31. Antoshechkin, A. G. (2001). On intracellular formation of ethanol and its possible role in energy metabolism. Alcohol and Alcoholism, 36(6), 608.

32. Haffner, H. T., Graw, M., Besserer, K., Blickle, U., \& Henßge, C. (1996). Endogenous methanol: Variability in concentration and rate of production. Evidence of a deep compartment? Forensic Science International, 79(2), 145-154.

33. Lindinger, W., Taucher, J., Jordan, A., Hansel, A., \& Vogel, W. (1997). Endogenous production of methanol after the consumption of fruit. Alcoholism, Clinical and Experimental Research, 21(5), 939-943.

34. Karch, S. B. (2007). Drug abuse handbook (2nd ed.). New York: CRC Press.

35. Dorokhov, Y. L., Shindyapina, A. V., Sheshukova, E. V., \& Komarova, T. V. (2015). Metabolic methanol: Molecular pathways and physiological roles. Physiological Reviews, 95, 603-644.

36. Kistler, M., Szymczak, W., Fedrigo, M., Fiamoncini, J., Höllriegl, V., Hoeschen, C., et al. (2014). Effects of diet-matrix on volatile organic compounds in breath in diet-induced obese mice. Journal of Breath Research. doi:10.1088/1752-7155/8/1/ 016004.

37. Cope, K., Risby, T., \& Diehl, A. M. (2000). Increased gastrointestinal ethanol production in obese mice: Implications for fatty liver disease pathogenesis. Gastroenterology, 119, 1340-1347.

38. Davis, P. L., Cortivo, L. A. D., \& Maturo, J. (1984). Endogenous isopropanol: Forensic and biochemical implications. Journal of Analytical Toxicology, 8, 209-212.

39. Quertemont, E., \& Didone, V. (2006). Role of acetaldehyde in mediating the pharmacological and behavioral effects of alcohol. Alcohol Research \& Health, 29(4), 258-265.

40. Lärstad, M. A., Torén, K., Bake, B., \& Olin, A. C. (2007). Determination of ethane, pentane and isoprene in exhaled airEffects of breath-holding, flow rate and purified air. Acta Physiologica, 189, 87-98.

41. Sarbacha, C., Stevensb, P., Whitingb, J., Pugetc, P., Humbert, M., Cohen-Kaminsky, S., et al. (2013). Evidence of endogenous volatile organic compounds as biomarkers of diseases in alveolar breath. Annales Pharmaceutiques Françaises, 71, 203-215.

42. Ross, B. M., Maxwell, R., \& Glen, I. (2011). Increased breath ethane levels in medicated patients with schizophrenia and bipolar disorder are unrelated to erythrocyte omega-3 fatty acid abundance. Progress in Neuro-Psychopharmacology and Biological Psychiatry, 35, 446-453.

43. Kneepken, C. M. F., Lepage, G., \& Roy, C. C. (1994). The potential of the hydrocarbon breath test as a measure of lipid peroxidation. Free Radical Biology and Medicine, 17, 127-160. 
44. Dumelin, E. E., \& Tappel, A. L. (1977). Hydrocarbon gases produced during in vitro peroxidation of polyunsaturated fatty acids and decomposition of preformed hydroperoxides. Lipids, 12, 894-900.

45. Zhou, M., Liu, Y., \& Duan, Y. (2012). Breath biomarkers in diagnosis of pulmonary diseases. Clinica Chimica Acta, 413, $1770-1780$.

46. Aghdassi, E., \& Allard, J. P. (2000). Breath alkanes as a marker of oxidative stress in different clinical conditions. Free Radical Biology and Medicine, 28, 880-886.

47. Phillips, M., Cataneo, R. N., Greenberg, J., Grodman, R., Gunawardena, R., \& Naidu, A. (2003). Effect of oxygen on breath markers of oxidative stress. European Respiratory Journal, 21, 48-51.

48. Phillips, M., Cataneo, R. N., Greenberg, J., Gunawardena, R., \& Rahbari-Oskoui, F. (2003). Increased oxidative stress in younger as well as in older humans. Clinica Chimica Acta, 328, 83-86.

49. Pryor, W. A. (1982). Free radical biology: Xenobiotics, cancer and aging. Annals of the New York Academy of Sciences, 339, $1-22$.

50. Schreck, R., Rieber, P., \& Baeuerle, P. A. (1991). Reactive oxygen intermediates as apparently widely used messengers in the activation of the NF-kb transcription factor and HIV-1. The EMBO Journal, 10(8), 2247-2258.

51. Harris, M. L., Schiller, H. J., Reilly, P. M., Donowitz, M., Grisham, M. B., \& Bulkley, G. B. (1992). Free radicals and other reactive oxygen metabolites in inflammatory bowel disease. Cause, consequence, or epiphenomena? Pharmacology \& Therapeutics, 53(3), 375-408.

52. Mitsui, T., \& Kondo, T. (2003). Inadequacy of theoretical basis of breath methylated alkane contour for assessing oxidative stress. Clinica Chimica Acta, 333(1), 91.

53. Risby, T. H., \& Sehnert, S. S. (1999). Clinical application of breath biomarkers of oxidative stress status. Free Radical Biology and Medicine, 27, 1182-1192.

54. Kohlmüller, D., \& Kochen, W. (1993). Is n-pentane really an index of lipid peroxidation in humans and animals? A methodological reevaluation. Analytical Biochemistry, 210(2), 268-276.

55. Paredi, P., Kharitonov, S. A., \& Barnes, P. J. (2000). Elevation of exhaled ethane concentration in asthma. American Journal of Respiratory and Critical Care Medicine, 162, 1450-1454.

56. Paredi, P., Kharitonov, S. A., Leak, D., Shah, P. L., Cramer, D., Hodson, M. E., et al. (2000). Exhaled ethane is elevated in cystic fibrosis and correlates with carbon monoxide levels and airway obstruction. American Journal of Respiratory and Critical Care Medicine, 161, 1247-1251.

57. Paredi, P., Kharitonov, S. A., Leak, D., Ward, S., Cramer, D., \& Barnes, P. J. (2000). Exhaled ethane, a marker of lipid peroxidation, is elevated in chronic obstructive pulmonary disease. American Journal of Respiratory and Critical Care Medicine, 162, 369-373.

58. Olopade, C. O., Zakkar, M., Swedler, W. I., \& Rubinstein, I. (1997). Exhaled pentane levels in acute asthma. Chest, 111, 862-865.

59. Conkle, J. P., Camp, B. J., \& Welch, B. E. (1975). Trace composition of human respiratory gas. Archives of Environmental Health, 30, 290-295.

60. Gelmont, D., Stein, R. A., \& Mead, J. F. (1981). Isoprene-The main hydrocarbon in human breath. Biochemical and Biophysical Research Communications, 99, 1456-1460.

61. Cikach, F. S., Jr., \& Dweik, R. A. (2012). Cardiovascular biomarkers in exhaled breath. Progress in Cardiovascular Diseases, 55, 34-43.

62. Meinardi, S., Jin, K. B., Barletta, B., Blake, D. R., \& Vaziri, N. D. (2013). Exhaled breath and fecal volatile organic biomarkers of chronic kidney disease. Biochimica et Biophysica Acta, 1830, 2531-2537.

63. Sharkey, T. D., Wiberley, A. E., \& Donohue, A. R. (2008). Isoprene emission from plants: Why and how. Annals of Botany, $101,5-18$.

64. King, J., Koc, H., Unterkofler, K., Mochalski, P., Kupferthaler, A., Teschl, G., et al. (2010). Physiological modeling of isoprene dynamics in exhaled breath. Journal of Theoretical Biology, 267, 626-637.

65. Betyia, E. D., \& Porter, J. W. (1976). Biochemistry of polyisoprenoid biosynthesis. Annual Review of Biochemistry, 45, 113-142.

66. Deneris, E. S., Stein, R. A., \& Mead, J. F. (1984). In vitro biosynthesis of isoprene from mevalonate utilizing a rat liver cytosolic fraction. Biochemical and Biophysical Research Communications, 123(2), 691-696.

67. King, J., Mochalski, P., Unterkofler, K., Teschl, G., Klieber, M., Stein, M., et al. (2012). Breath isoprene: Muscle dystrophy patients support the concept of a pool of isoprene in the periphery of the human body. Biochemical and Biophysical Research Communications, 423, 526-530.

68. Kuzma, J., Nemecek-Marshall, M., Pollock, W. H., \& Fall, R. (1995). Bacteria produce the volatile hydrocarbon isoprene. Current Microbiology, 30, 97-103.

69. Stone, B. G., Besse, T. J., Duane, W. C., Evans, C. D., \& DeMaster, E. G. (1993). Effect of regulating cholesterol biosynthesis on breath isoprene excretion in men. Lipids, 28(8), 705-708.

70. Scholpp, J., Schubert, J. K., Miekisch, W., \& Geiger, K. (2002). Breath markers and soluble lipid peroxidation markers in critically ill patients. Clinical Chemistry and Laboratory Medicine, 40, 587-594.

71. McGrath, L. T., Patrick, R., Mallon, P., Dowey, L., Silke, B., Norwood, W., et al. (2000). Breath isoprene during acute respiratory exacerbation in cystic fibrosis. European Respiratory Journal, 16, 1065-1069.

72. Nelson, N., Lagesson, V., Nosratabadi, A. R., Ludvigsson, J., \& Tagesson, C. (1998). Exhaled isoprene and acetone in newborn infants and in children with diabetes mellitus. Pediatric Research. doi:10.1203/00006450-199809000-00016.

73. King, J., Kupferthaler, A., Unterkofler, K., Koc, H., Teschl, S., Teschl, G., et al. (2009). Isoprene and acetone concentration profiles during exercise on an ergometer. Journal of Breath Research. doi:10.1088/1752-7155/3/2/027006.

74. Salerno-Kennedy, R., \& Cashman, K. D. (2005). Potential applications of breath isoprene as a biomarker in modern medicine: A concise overview. Wiener Klinische Wochenschrift, 117, 180-186.

75. Amann, A., Corradi, M., Mazzone, P., \& Mutti, A. (2011). Lung cancer biomarkers in exhaled breath. Expert Review of Molecular Diagnostics., 11(2), 207-217.

76. Scislowski, P. W. D., \& Pickard, K. (1994). The regulation of transaminative flux of methionine in rat liver mitochondria. Achieves of Biochemestry and Biophysics, 314(2), 412-416.

77. Van den Velde, S., Nevens, F., Van Hee, P., van Steenberghe, D., \& Quirynen, M. (2008). GC-MS analysis of breath odor compounds in liver patients. Journal of Chromatography B, 875(2), 344-348.

78. Tangerman, A., Meuwese-Arends, M. T., \& van Tongeren, J. H. M. (1983). A new sensitive assay for measuring volatile sulphur compounds in human breath by Tenax trapping and gas chromatography and its application in liver cirrhosis. Clinica Chimica Acta, 130(1), 103-110.

79. Tangerman, A., Meuwese-Arends, M. T., \& Jansen, J. B. (1994). Cause and composition of foetor hepaticus. The Lancet, 343(8895), 483. 
80. Smith, A., Heckelman, P. A., O’Neil, M. J., \& Budavari, S. (2001). The Merck index. Rahway, NJ: Merck Publishing.

81. Filipiak, W., Sponring, A., Baur, M. M., Ager, C., Filipiak, A., Wiesenhofer, H., et al. (2012). Characterization of volatile metabolites taken up by or released from Streptococcus pneumoniae and Haemophilus influenzae by using GC-MS. Microbiology, 158, 3044-3053.

82. Simenhoff, M. L., Burke, J. F., Saukkonen, J. J., Ordinario, A. T., \& Doty, R. (1977). Biochemical profile or uremic breath. The New England Journal of Medicine., 297, 132-135.

83. Turner, C., Španěl, P., \& Smith, D. (2006). A longitudinal study of ammonia, acetone and propanol in the exhaled breath of 30 subjects using selected ion flow tube mass spectrometry, SIFTMS. Physiological Measurement, 27(4), 321-337.

84. Davies, S., Spanel, P., \& Smith, D. (1997). Quantitative analysis of ammonia on the breath of patients in end-stage renal failure. Kidney International, 52, 223-228.

85. Schroedinger, E. (1944). What's life?. New York: Cambridge University Press.

86. Aksenov, A. A., Gojova, A., Zhao, W., Morgan, J. T., Sankaran, S., Sandrock, C. E., et al. (2012). Characterization of volatile organic compounds in human leukocyte antigen heterologous expression systems: A cell's 'chemical odor fingerprint'. ChemBioChem, 13(7), 1053-1059.

87. Wlodzimirow, K. A., Abu-Hanna, A., Schultz, M. J., Maas, M. A., Bos, L. D., Sterk, P. J., et al. (2014). Exhaled breath analysis with electronic nose technology for detection of acute liver failure in rats. Biosensors \& Bioelectronics, 53, 129-134.

88. Davies, M. P., Barash, O., Jeries, R., Peled, N., Ilouze, M., Hyde, R., et al. (2014). Unique volatolomic signatures of TP53 and KRAS in lung cells. British Journal of Cancer, 111, 1213-1221.

89. Fens, N., van der Schee, M. P., Brinkman, P., \& Sterk, P. J. (2013). Exhaled breath analysis by electronic nose in airways disease. Established issues and key questions. Clinical and Experimental Allergy, 43(7), 705-715.

90. Gorham, K. A., Sulbaek Andersen, M. P., Meinardi, S., Delfino, R. J., Staimer, N., Tjoa, T., et al. (2009). Ethane and n-pentane in exhaled breath are biomarkers of exposure not effect. Biomarkers, 14(1), 17-25.

91. Pleil, J. D., Pleil, J. D., Stiegel, M. A., \& Risby, T. H. (2013). Clinical breath analysis: Discriminating between human endogenous compounds and exogenous (environmental) chemical confounders. Journal of Breath Research. doi:10.1088/ 1752-7155/7/3/037110

92. Bos, L. D., Sterk, P. J., \& Schultz, M. J. (2013). Volatile metabolites of pathogens: A systematic review. PLoS Pathogens. doi:10.1371/journal.ppat.1003311.

93. Schulz, S., \& Dickschat, J. S. (2007). Bacterial volatiles: The smell of small organisms. Natural Product Report, 24, 814-842.

94. Libardoni, M., Stevens, P. T., Waite, J. H., \& Sacks, R. (2006). Analysis of human breath samples with a multi-bed sorption trap and comprehensive two-dimensional gas chromatography (GC $\times \mathrm{GC})$. Journal of Chromatography B, 842, 13-21.

95. Lehman-McKeeman, L. D. (2013). Absorption, distribution, and excretion of toxicants. In C. D. Klaassen (Ed.), Casarett and Dowll's toxicology: The basic science of poisons (pp. 153-183). New York: McGraw-Hill Education.

96. Wilson, H. K. (1986). Breath analysis: Physiological basis and sampling techniques. Scandinavian Journal of Work, Environment \& Health, 12(3), 174-192.

97. Buszewski, B., Kęsy, M., Ligor, T., \& Amann, A. (2007). Human exhaled air analytics: Biomarkers of diseases. Biomedical Chromatography, 21, 553-566.

98. Miekisch, W., \& Schubert, J. K. (2006). From highly sophisticated analytical techniques to life-saving diagnostics: Technical developments in breath Analysis. Trends in Analytical Chemistry, 25(7), 665-673.

99. Cao, W., \& Duan, Y. (2006). Breath analysis: Potential for clinical diagnosis and exposure assessment. Clinical Chemistry, 52(5), 800-811.

100. Alonso, M., \& Sanchez, J. M. (2013). Analytical challenges in breath analysis and its application to exposure monitoring. Trends in Analytical Chemistry, 44, 78-89.

101. Mandy, M., Cornelia, F., Malgorzata, L., Oliver, S., Achim, S., \& Dorothee, S. (2012). Volatile organic compounds (VOCs) in exhaled breath of patients with breast cancer in a clinical setting. Ginekologia Polska, 83, 730-736.

102. Andreoni, K. A., Kazui, M., Cameron, D. E., Nyhan, D., Sehnert, S. S., Rohde, C. A., et al. (1999). Ethane: A marker of lipid peroxidation during cardiopulmonary bypass in humans. Free Radical Biology and Medicine, 26, 439-444.

103. Kazui, M., Andreoni, K. A., Williams, G. M., Perler, B. A., Bulkley, G. B., Beatti, C., et al. (1994). Visceral lipid peroxidation occurs at reperfusion after supraceliac aortic crossclamping. Journal of Vascular Surgery, 19, 473-477.

104. Kazui, M., Andreoni, K. A., Norris, E. J., Klein, A. S., Burdick, J. F., Beattie, C., et al. (1992). Breath ethane: A specific indicator of freeradical-mediated lipid peroxidation following reperfusion of the ischemic liver. Free Radical Biology and Medicine, 13, 509-515.

105. Weitz, Z. W., Birnbaum, A. J., Skosey, J. L., Sobotka, P. A., \& Zarling, E. J. (1991). High breath pentane concentrations during acute myocardial infarction. The Lancet, 337, 933-935.

106. Mendis, S., Sobotka, P. A., Leja, F. L., \& Euler, D. E. (1995). Breath pentane and plasma lipid peroxides in ischemic heart disease. Free Radical Biology and Medicine, 19, 679-684.

107. McGrath, L. T., Patrick, R., \& Silke, B. (2001). Breath isoprene in patients with heart failure. European Journal of Heart Failure, 3, 423-427.

108. Schubert, J. K., Müller, W. P., Benzing, A., \& Geiger, K. (1998). Application of a new method for analysis of exhaled gas in critically ill patients. Intensive Care Medicine, 24(5), 415-421.

109. Senthilmohan, S. T., McEwan, M. J., Wilson, P. F., Milligan, D. B., \& Freeman, C. G. (2001). Real time analysis of breath volatiles using SIFT-MS in cigarette smoking. Redox Report: Communications in Free Radical Research, 6, 185-187.

110. Trovarelli, G., Brunori, F., De Medio, G. E., Timio, M., Lippi, G., Pelli, M. A., et al. (2001). Onset, time course and persistence of increased heamodialysis-induced breath isoprene emission. Nephron, 88, 44-47.

111. Sehnert, S. S., Jiang, L., Burdick, J. F., \& Risby, T. H. (2002). Breath biomarkers for detection of human liver diseases: Preliminary study. Biomarkers, 7(2), 174-187.

112. Tangerman, A., Meuwese-Arends, M. T., \& van Tongeren, J. H. (1985). New methods for the release of volatile sulfur compounds from human serum: Its determination by Tenax trapping and gas chromatography and its application in liver diseases. Journal of Laboratory and Clinical Medicine, 106(2), 175-182.

113. Lebovitz, H. E. (1995). Diabetic ketoacidosis. The Lancet, 345 , 767-772.

114. Kearney, D. J., Hubbard, T., \& Putnam, D. (2002). Breath ammonia measurement in helicobacter pylori infection. Digestive Diseases and Sciences, 47(11), 2523-2530.

115. Kundra, A., Jain, A., Banga, A., Bajaj, G., \& Kar, P. (2005). Evaluation of plasma ammonia levels in patients with acute liver failure and chronic liver disease and its correlation with the severity of hepatic encephalopathy and clinical features of raised intracranial tension. Clinical Biochemistry, 38, 696-699.

116. Seiler, N. (2002). Ammonia and Alzheimer's disease. Neurochemistry International, 41, 189-207. 
117. Humphreys, L., Orme, R. M. L'. E., Moore, P., Charaklias, N., Sahgal, N., Pont, N. P., et al. (2011). Electronic nose analysis of bronchoalveolar lavage fluid. European Journal of Clinical Investigation, 41, 52-58.

118. Hockstein, N. G., Thaler, E. R., Torigian, D., Miller, W. T., Jr., Deffenderfer, O., \& Hanson, C. W. (2004). Diagnosis of pneumonia with an electronic nose: Correlation of vapor signature with chest computed tomography scan findings. The Laryngoscope, 114, 1701-1705.

119. Hanson, C. W., \& Thaler, E. R. (2005). Electronic nose prediction of clinical pneumonia score: Biosensors and microbes. Anesthesiology, 102, 63-68.

120. Fens, N., Roldaan, A. C., van der Schee, M. P., Boksem, R. J., Zwinderman, A. H., Bel, E. H., et al. (2011). External validation of exhaled breath profiling using an electronic nose in the discrimination of asthma with fixed airways obstruction and chronic obstructive pulmonary disease. Clinical and Experimental Allergy, 41, 1371-1378.

121. Fens, N., Zwinderman, A. H., van der Schee, M. P., de Nijs, S. B., Dijkers, E., Roldaan, A. C., et al. (2009). Exhaled breath profiling enables discrimination of chronic obstructive pulmonary disease and asthma. American Journal of Respiratory and Critical Care Medicine, 180, 1076-1082.

122. Valera, J. S., Togores, B., \& Cosio, B. G. (2012). Use of the electronic nose for diagnosing respiratory diseases. Archivos de Bronconeumología, 48(6), 187-188.

123. Dragonieri, S., Schot, R., Mertens, B. J. A., Le Cessie, S., Gauw, S. A., Spanevello, A., et al. (2007). An electronic nose in the discrimination of patients with asthma and controls. Journal of Allergy and Clinical Immunology, 120(4), 856-862.

124. Montuschi, P., Santonico, M., Mondino, C., Pennazza, G., Mantini, G., Martinelli, E., et al. (2010). Diagnostic performance of an electronic nose, fractional exhaled nitric oxide, and lung function testing in asthma. Chest, 137(4), 790-796.

125. Kolk, A., Hoelscher, M., Maboko, L., Jung, J., Kuijper, S., Cauchi, M., et al. (2010). Electronic-nose technology using sputum samples in diagnosis of patients with tuberculosis. Journal of Clinical Microbiology, 48(11), 4235-4238.

126. Bruins, M., Rahim, Z., Bos, A., van de Sande, W. W. J., Endtz, H. P., van Belkum, A., et al. (2013). Diagnosis of active tuberculosis by e-nose analysis of exhaled air. Tuberculosis, 93, 232-238.

127. Phillips, M., Cataneo, R. N., Condos, R., Ring Erickson, G. A., Greenberg, J., La Bombardi, V., et al. (2007). Volatile biomarkers of pulmonary tuberculosis in the breath. Tuberculosis, 87, 44-52.

128. Greulich, T., Hattesohl, A., Grabisch, A., Koepke, J., Schmid, S., Noeske, S., et al. (2013). Detection of obstructive sleep apnoea by an electronic nose. European Respiratory Journal, 42, 145-155.

129. Benedek, P., Lázár, Z., Bikov, A., Kunos, L., Katona, G., \& Horváth, I. (2013). Exhaled biomarker pattern is altered in children with obstructive sleep apnoea syndrome. International Journal of Pediatric Otorhinolaryngology, 77, 1244-1247.

130. Kunos, L., Bikov, A., Lazar, Z., Korosi, B. Z., Benedek, P., Losonczy, G., et al. (2015). Evening and morning exhaled volatile compound patterns are different in obstructive sleep apnoea assessed with electronic nose. Sleep and Breathing, 19(1), 247-253.

131. Machado, R. F., Laskowski, D., Deffenderfer, O., Burch, T., Zheng, S., Mazzone, P. J., et al. (2005). Detection of lung cancer by sensor array analyses of exhaled breath. American Journal of Respiratory and Critical Care Medicine, 171, 1286-1291.

132. Dragonieri, S., Annema, J. T., Schot, R., van der Schee, M. P. C., Spanevello, A., Carratú, P., et al. (2009). An electronic nose in the discrimination of patients with non-small cell lung cancer and COPD. Lung Cancer, 64, 166-170.

133. Di Natale, C., Macagnano, A., Martinelli, E., Paolesse, R., D’Arcangelo, G., Roscioni, R., et al. (2003). Lung cancer identification by the analysis of breath by means of an array of non-selective gas sensors. Biosensors \& Bioelectronics, 18, 1209-1218.

134. Chen, X., Cao, M., Li, Y., Hu, W., Wang, P., Ying, K., et al. (2007). A study of an electronic nose for detection of lung cancer based on surface acoustic wave sensors and image recognition method. Measurement Science \& Technology, 16, $1535-1546$.

135. Van Berkel, J. J., Dallinga, J. W., Möller, G. M., Godschalk, R. W., Moonen, E. J., Wouters, E. F., et al. (2010). A profile of volatile organic com-pounds in breath discriminates COPD patients from controls. Respiratory Medicine, 104, 557-563.

136. Boots, A. W., van Berkel, J. J., Dallinga, J. W., Smolinska, A., Wouters, E. F., \& van Schooten, F. J. (2012). The versatile use of exhaled volatile organic compounds in human health and disease. Journal of Breath Research. doi:10.1088/1752-7155/6/ 2/027108.

137. Mieth, M., Schubert, J. K., Gröger, T., Sabel, B., Kischkel, S., Fuchs, P., et al. (2010). Automated needle trap heart-cut GC/MS and needle trap comprehensive two-dimensional GC/TOF-MS for breath gas analysis in the clinical environment. Analytical Chemistry, 82, 2541-2551.

138. Awano, S., Koshimune, S., Kurihara, E., Gohara, K., Sakai, A., Soh, I., et al. (2004). The assessment of methyl mercaptan, an important clinical marker for the diagnosis of oral malodor. Journal of Dentistry, 32(7), 555-559.

139. Chambers, S. T., Shyre, M., Murdoch, D. R., McCartin, F., \& Epton, M. J. (2009). Detection of 2-pentylfuran in the breath of patients with Aspergillus fumigatus. Medical Mycology, 47(5), 468-476.

140. Syhre, M., Scotter, J., \& Chambers, S. T. (2008). Investigation into the production of 2-pentylfuran by Aspergillus fumigatus and other respiratory pathogens in vitro and human breath samples. Medical Mycology, 46(3), 209-215.

141. Hansel, A., Jordana, A., Holzingera, R., Prazellera, P., Vogel, W., \& Lindingera, W. (1995). Proton transfer reaction mass spectrometry: On-line trace gas analysis at ppb level. International Journal of Mass Spectrometry and Ion Processes, 149-150, 609-619.

142. Prazeller, P., Palmer, P. T., Boscaini, E., Jobson, T., \& Alexander, M. (2003). Proton transfer reaction ion trap mass spectrometer. Rapid Communications in Mass Spectrometry, 17, 1593-1599.

143. Harrison, G. R., Critchley, A. D., Mayhew, C. A., \& Thompson, J. M. (2003). Real-time breath monitoring of propofol and its volatile metabolites during surgery using a novel mass spectrometric technique: a feasibility study. British Journal of Anaesthesia, 91(6), 797-799.

144. Moser, B., Bodrogi, F., Eibl, G., Lechner, M., Rieder, J., \& Lirk, P. (2005). Mass spectrometric profile of exhaled breath-field study by PTR-MS. Respiratory Physiology \& Neurobiology, 145, 295-300.

145. Lirk, P., Bodrogi, F., Raifer, H., Greiner, K., Ulmer, H., \& Rieder, J. (2003). Elective haemodialysis increases exhaled isoprene. Nephrology, Dialysis, Transplantation, 18, 937-941.

146. Smith, D., \& Španěl, P. (2011). Ambient analysis of trace compounds in gaseous media by SIFT-MS. Analyst, 136(10), 2009-2032.

147. Španěl, P., \& Smith, D. (2011). Progress in SIFT-MS: Breath analysis and other applications. Mass Spectrometry Reviews, 30(2), 236-267. 
148. Prince, B. J., Milligan, D. B., \& McEwan, M. J. (2010). Application of selected ion flow tube mass spectrometry to realtime atmospheric monitoring. Rapid Communications in Mass Spectrometry, 24(12), 1763-1769.

149. Davis, B. M., Senthilmohan, S. T., Wilson, P. F., \& McEwan, M. J. (2005). Major volatile compounds in head-space above olive oil analysed by selected ion flow tube mass spectrometry. Rapid Communications in Mass Spectrometry, 19(16), 2272-2278.

150. Tang, Z., Liu, Y., \& Duan, Y. (2015). Breath analysis: Technical developments and challenges in the monitoring of human exposure to volatile organic compounds. Journal of Chromatography B, 1002, 285-299.

151. Persaud, K. C., Khaffaf, S. M., Payne, J. S., Pisanelli, A. M., Lee, D. H., \& Byun, H. G. (1996). Sensor array techniques for mimicking the mammalian olfactory system. Sensors and Actuators B: Chemical, 36, 267-273.

152. Preti, G., Thaler, E., Hanson, W., Troy, M., Eades, J., \& Gelperin, A. (2009). Volatile compounds characteristic of sinusrelated bacteria and infected sinus mucus: Analysis by solidphase microextraction and gas chromatography-mass spectrometry. Journal of Chromatography B, 877(22), 2011-2018.

153. Trincavelli, M., Coradeschi, S., Loutfi, A., Söderquist, B., \& Thunberg, P. (2010). Direct identification of bacteria in blood culture samples using an electronic nose. IEEE Transactions on Biomedical Engineering, 57(12), 2884-2890.

154. Lin, Y. J., Guo, H. R., Chang, Y. H., Kao, M. T., Wang, H. H., \& Hong, R. I. (2001). Application of the electronic nose for uremia diagnosis. Sensors and Actuators B: Chemical, 76, 177-180.

155. Bdeir, K., Higazi, A. A., Kulikovskaya, I., Christofidou-Solomidou, M., Vinogradov, S. A., Allen, T. C., et al. (2010). Neutrophil $\alpha$-defensins cause lung injury by disrupting the capillary-epithelial barrier. American Journal of Respiratory and Critical Care Medicine, 181, 935-946.

156. Guo, D., Zhang, D., Li, N., Zhang, L., \& Yang, J. (2010). A novel breath analysis system based on electronic olfaction. IEEE Transactions on Biomedical Engineering, 57(11), 2753-2763.

157. Dragonieri, S., van der Schee, M. P., Massaro, T., Schiavulli, N., Brinkman, P., Pinca, A., et al. (2012). An electronic nose distinguishes exhaled breath of patients with malignant pleural mesothelioma from controls. Lung Cancer, 75, 326-331.

158. Xie, Z., Ruzsanyi, V., Sielemann, S., Schmidt, H., \& Baumbach, J. I. (2001). Determination of pentane, isoprene and acetone using HSCC-UV-IMS. International Journal for Ion Mobility Spectrometry, 4, 88-91.

159. Steiner, W. E., Clowers, B. H., English, W. A., \& Hill, H. H., Jr. (2004). Atmospheric pressure matrix-assisted laser desorption/ ionization with analysis by ion mobility time-of-flight mass spectrometry. Rapid Communications in Mass Spectrometry, 18(8), 882-888.

160. Li, F., Xie, Z., Schmidt, H., Sielemann, S., \& Baumbach, J. I. (2002). Ion mobility spectrometer for online monitoring of trace compounds. Spectrochimica Acta, Part B: Atomic Spectroscopy, 57(10), 1563-1574.

161. Ruzsanyi, V., Baumbach, J. I., Sielemann, S., Litterst, P., Westhoff, M., \& Freitag, L. (2005). Detection of human metabolites using multi-capillary columns coupled to ion mobility spectrometers. Journal of Chromatography A, 1084, $145-151$.

162. Baumbach, J., Vautz, W., Ruzsanyi, V., \& Freitag, L. (2005). Metabolites in human breath: Ion mobility spectrometers as diagnostic tools for lung diseases. In A. Amann \& D. Smith (Eds.), Breath analysis for clinical diagnostics and therapeutic monitoring (pp. 53-66). London: World Scientific.

163. Westhoff, M., Litterst, P., Freitag, L., Urfer, W., Bader, S., \& Baumbach, J. I. (2009). Ion mobility spectrometry for the detection of volatile organic compounds in exhaled breath of patients with lung cancer: Results of a pilot study. Thorax, 64, 744-748.

164. Sandrini, A., Taylor, D. R., Thomas, P. S., \& Yates, D. H. (2010). Fractional exhaled nitric oxide in asthma: An update. Respirology, 15(1), 57-70.

165. Yan, K., Zhang, D., Wu, D., Wei, H., \& Lu, G. (2014). Design of a breath analysis system for diabetes screening and blood glucose level prediction. IEEE Transactions on Biomedical Engineering, 61(11), 2787-2795.

166. Tian, K., Prestgard, M., \& Tiwari, A. (2014). A review of recent advances in nonenzymatic glucose sensors. Materials Science and Engineering $C, 41,100-118$.

167. Allman, T. (2008). Diabetes. New York: Infobase Publishing.

168. Danaei, G., Finucane, M. M., Lu, Y., Singh, G. M., Cowan, M. J., Paciorek, P. J., et al. (2011). National, regional, and global trends in fasting plasma glucose and diabetes prevalence since 1980: Systematic analysis of health examination surveys and epidemiological studies with 370 country-years and 2.7 million participants. The Lancet, 378(9785), 31-40.

169. Alwan, A. (2011). Global status report on noncommunicable diseases 2010. Geneva: World Health Organization. http://www. who.int $/ \mathrm{nmh} /$ publications/ncd_report_full_en.pdf.

170. Keen, H., \& Fui, S. N. T. (1982). The definition and classification of diabetes mellitus. Clinics in Endocrinology and Metabolism, 11(2), 279-305.

171. Shaw, K. M., \& Cummings, M. H. (Eds.). (2005). Diabetes: Chronic complications. Chichester: Wiley.

172. Masharani, U. (2008). Diabetes demystified. New York: The McGraw-Hill.

173. Halbritter, S., Fedrigo, M., Höllriegl, V., Szymczak, W., Maier, J. M., Ziegler, A. G., et al. (2012). Human breath gas analysis in the screening of gestational diabetes mellitus. Diabetes Technology \& Therapeutics, 14(10), 917-925.

174. Minh, T. D. C., Blake, D. R., \& Galassetti, P. R. (2012). The clinical potential of exhaled breath analysis for diabetes mellitus. Diabetes Research and Clinical Practice, 97(2), 195-205.

175. Turner, C. (2011). Potential of breath and skin analysis for monitoring blood glucose concentration in diabetes. Expert Review of Molecular Diagnostics, 11(5), 497-503.

176. Tabák, A. G., Jokela, M., Akbaraly, T. N., Brunner, E. J., Kivimäki, M., \& Witte, D. R. (2009). Trajectories of glycaemia, insulin sensitivity, and insulin secretion before diagnosis of type 2 diabetes: An analysis from the Whitehall II study. The Lancet, 373, 2215-2221.

177. Blaak, E. E. (2005). Metabolic fluxes in skeletal muscle in relation to obesity and insulin resistance. Best Practice \& Research Clinical Endocrinology \& Metabolism, 19, 391-403.

178. Laffel, L. (1999). Ketone bodies: A review of physiology, pathophysiology and application of monitoring to diabetes. $D i$ abetes Metabolism Research and Reviews, 15, 412-426.

179. Ramachandran, A., Moses, A., Shetty, S., Thirupurasundari, C. J., Seeli, A. C., Snehalatha, C., et al. (2010). A new non-invasive technology to screen for dysglycemia including diabetes. Diabetes Research and Clinical Practice, 88(3), 302-306.

180. Vashist, S. K. (2012). Non-invasive glucose monitoring technology in diabetes management: A review. Analytica Chimica Acta, 750, 16-27.

181. Girardin, C. M., Huot, C., Gonthier, M., \& Delvin, E. (2009). Continuous glucose monitoring: A review of biochemical perspectives and clinical use in type 1 diabetes. Clinical Biochemistry, 42, 136-142.

182. Risby, T. H., \& Solga, S. (2006). Current status of clinical breath analysis. Applied Physics B: Lasers and Optics, 85(2), 421-426.

183. Deng, C., Zhang, J., Yu, X., Zhang, W., \& Zhang, X. (2004). Determination of acetone in human breath by gas 
chromatography-mass spectrometry and solid-phase microextraction with on-fiber derivatization. Journal of Chromatography B, 810(2), 269-275.

184. Ueta, I., Saito, Y., Hosoe, M., Okamoto, M., Ohkita, H., Shirai, S., et al. (2009). Breath acetone analysis with miniaturized sample preparation device: In-needle preconcentration and subsequent determination by gas chromatography-mass spectroscopy. Journal of Chromatography B, 877(24), 2551-2556.

185. Wang, C., Mbi, A., \& Shepherd, M. (2010). A study on breath acetone in diabetic patients using a cavity ringdown breath analyzer: Exploring correlations of breath acetone with blood glucose and glycohemoglobin A1C. IEEE Sensors Journal, $10(1), 54-63$.

186. Righettoni, M., Schmid, A., Amann, A., \& Pratsinis, P. E. (2013). Correlations between blood glucose and breath components from portable gas sensors and PTR-TOF-MS. Journal of Breath Research. doi:10.1088/1752-7155/7/3/037110.

187. Ghimenti, S., Tabucchi, S., Lomonaco, T., Di Francesco, F., Fuoco, R., Onor, M., et al. (2013). Monitoring breath during oral glucose tolerance tests. Journal of Breath Research. doi:10. 1088/1752-7155/7/1/017115.

188. van den Borst, B., Gosker, H. R., Zeegers, M. P., \& Schols, A. M. (2010). Pulmonary function in diabetes: A metaanalysis. Chest, 138(2), 393-406.

189. Weynand, B., Jonckheere, A., Frans, A., \& Rahier, J. (1999). Diabetes mellitus induces a thickening of the pulmonary basal lamina. Respiration, 66, 14-19.

190. Saraheimo, M., Forsblom, C., Pettersson-Fernholm, K., Flyvbjerg, A., Groop, P. H., \& Frystyk, J. (2008). Increased levels of $\alpha$-defensin $(-1,-2$ and -3$)$ in type 1 diabetic patients with nephropathy. Nephrology Dialysis Transplantation, 23(3), 914-918.

191. Rosa, J. S., Oliver, S. R., Flores, R. L., Ngo, J., Milne, G. L., Zaldivar, F. P., et al. (2011). Altered inflammatory, oxidative, and metabolic responses to exercise in pediatric obesity and type 1 diabetes. Pediatric Diabetes, 12, 464-472.

192. Quinn, K., Henriques, M., Parker, T., Slutsky, A. S., \& Zhang, H. (2008). Human neutrophil peptides: A novel potential mediator of inflammatory cardiovascular diseases. American Journal of Physiology-Heart and Circulatory Physiology. doi:10.1152/ajpheart.00472.2008.

193. Watson, A. M. D., Soro-Paavonen, A., \& Jandeleit-Dahm, K. A. (2010). AGE-RAGE signalling in endothelial dysfunction and atherosclerosis in diabetes. In S. Dauphinee \& A. Karsan (Eds.), Endothelial dysfunction and inflammation (pp. 161-174). Basel: Springer.

194. Lopez-Lopez, J. G., Moral-Sanz, J., Frazziano, G., Gomez-Villalobos, M. J., Flores-Hernandez, J., Monjaraz, E., et al. (2008). Diabetes induces pulmonary artery endothelial dysfunction by NADPH oxidase induction. American Journal of PhysiologyLung Cellular and Molecular Physiology. doi:10.1152/ajplung. 90354.2008.

195. Guo, D., Zhang, D., Zhang, L., \& Lu, G. (2012). Non-invasive blood glucose monitoring for diabetics by means of breath signal analysis. Sensors and Actuators B, 173, 106-113.

196. Rooth, G., \& Ostenson, S. (1966). Acetone in alveolar air, and the control of diabetes. The Lancet, 2, 1102-1105.

197. Tassopoulos, C., Barnett, D., \& Fraser, T. R. (1969). Breathacetone and blood-sugar measurements in diabetes. The Lancet, 293, 1282-1286.

198. Galassetti, P. R., Novak, B., Nemet, D., Rose-Gottron, C., Cooper, D. M., Meinardi, S., et al. (2005). Breath ethanol and acetone as indicators of serum glucose levels: An initial report. Diabetes Technology \& Therapeutics, 7(1), 115-123.

199. Buszewski, B., Ligor, T., Jezierski, T., Wenda-Piesik, A., Walczak, M., \& Rudnicka, J. (2012). Identification of volatile lung cancer markers by gas chromatography-mass spectrometry: Comparison with discrimination by canines. Analytical and Bioanalytical Chemistry, 404, 141-146.

200. Fan, G. T., Yang, C. L., Lin, C. H., Chen, C. C., \& Shih, C. H. (2014). Applications of Hadamard transform-gas chromatography/mass spectrometry to the detection of acetone in healthy human and diabetes mellitus patient breath. Talanta, 120, 386-390.

201. Turner, C., Walton, C., Hoashi, S., \& Evans, M. (2009). Breath acetone concentration decreases with blood glucose concentration in type I diabetes mellitus patients during hypoglycaemic clamps. Journal of Breath Research. doi:10.1088/1752-7155/3/ 4/046004.

202. Kistler, M., Muntean, A., Szymczak, W., Rink, N., Fuchs, H., Gailus-Durner, V., et al. (2016). Diet-induced and mono-genetic obesity alter volatile organic compound signature in mice. Journal of Breath Research. doi:10.1088/1752-7155/10/1/016009.

203. Fink, T., Albrecht, F. W., Maurer, F., Kleber, A., Hüppe, T., Schnauber, K., et al. (2015). Exhalation pattern changes during fasting and low dose glucose treatment in rats. Analytical and Bioanalytical Chemistry, 407(13), 3763-3773.

204. Doong, M. L., \& Yang, H. (2003). Intravenous glucose infusion decreases intracisternal thyrotropin-releasing hormone induced vagal stimulation of gastric acid secretion in anesthetized rats. Neuroscience Letters, 340, 49-52.

205. Nicholas, N. J. W., Hamrang, Z., Trivedi, D. K., Goodacre, R., \& Fowler, S. J. (2014). Taking your breath away: Metabolomics breathes life into personalized medicine. Trends in Biotechnology, 32(10), 538-548.

206. Riess, U., Tegtbur, U., Fauck, C., Fuhrmann, F., Markewitz, D., \& Salthammer, T. (2010). Experimental setup and analytical methods for the non-invasive determination of volatile organic compounds, formaldehyde and $\mathrm{NO}_{\mathrm{x}}$ in exhaled human breath. Analytica Chimica Acta, 669, 53-62.

207. Pandey, S. K., \& Kim, K. H. (2011). Human body-odor components and their determination. Trends in Analytical Chemistry, 30(5), 784-796.

208. Poli, D., Carbognani, P., Corradi, M., Goldoni, M., Acampa, O., Balbi, B., et al. (2005). Exhaled volatile organic compounds in patients with non-small cell lung cancer: Cross sectional and nested short-term follow-up study. Respiratory Research. doi:10.1186/1465-9921-6-71.

209. Mitsui, T., Naitoh, K., Tsuda, T., Hirabayashi, T., \& Kondo, T. (2000). Is endogenous isoprene the only coeluting compound in the measurement of breath pentane? Clinica Chimica Acta, 299, 193-198.

210. Ueta, I., Mizuguchi, A., Okamoto, M., Sakamaki, H., Hosoe, M., Ishiguro, M., et al. (2014). Determination of breath isoprene and acetone concentration with a needle-type extraction device in gas chromatography-mass spectrometry. Clinica Chimica Acta, 430, 156-159.

211. Kischkel, S., Miekisch, W., Sawacki, A., Straker, E. M., Trefz, P., Amann, A., et al. (2010). Breath biomarkers for lung cancer detection and assessment of smoking related effects-Confounding variables, influence of normalization and statistical algorithms. Clinica Chimica Acta, 411, 1637-1644.

212. Grabowska-Polanowska, B., Faber, J., Skowron, M., Miarka, P., Pietrzycka, A., Śliwka, I., et al. (2013). Detection of potential chronic kidney disease markers in breath using gas chromatography with mass-spectral detection coupled with thermal desorption method. Journal of Chromatography A, 1301, 179-189.

213. Ulanowska, A., Kowalkowski, T., Hrynkiewicz, K., Jackowski, M., \& Buszewski, B. (2011). Determination of volatile organic compounds in human breath for Helicobacter pylori detection by SPME-GC/MS. Biomedical Chromatography, 25, 391-397. 
214. Minh, T. D. C., Oliver, S. R., Ngo, J., Flores, R., Midyett, J., Meinardi, S., et al. (2011). Noninvasive measurement of plasma glucose from exhaled breath in healthy and type 1 diabetic subjects. The American Journal of Physiology-Endocrinology and Metabolism. doi:10.1152/ajpendo.00634.2010.

215. Phillips, M., \& Greenberg, J. (1992). Ion-trap detection of volatile organic compounds in alveolar breath. Clinical Chemistry, 38, 60-65.

216. Handelman, G. J., Rosales, L. M., Barbato, D., Luscher, J., Adhikarla, R., Nicolosi, R. J., et al. (2003). Breath ethane in dialysis patients and control subjects. Free Radical Biology and Medicine, 35(1), 17-23.

217. Diskin, A. M., Śpaněl, P., \& Smith, D. (2003). Time variation of ammonia, acetone, isoprene and ethanol in breath: A quantitative SIFT-MS study over 30 days. Physiological Measurement, 24, 107-119.

218. Qin, T., Xu, X., Polák, T., Pacákováb, V., Štulik, K., \& Jech, L. (1997). A simple method for the trace determination of methanol, ethanol, acetone and pentane in human breath and in the ambient air by preconcentration on solid sorbents followed by gas chromatography. Talanta, 44, 1683-1690.

219. Zhang, G., Guo, X., Wang, S., Wang, X., Zhou, Y., \& Xu, H. (2014). New graphene fiber coating for volatile organic compounds analysis. Journal of Chromatography B, 969, 128-131.

220. Poli, D., Goldoni, M., Corradi, M., Acampa, O., Carbognani, P., Internullo, E., et al. (2010). Determination of aldehydes in exhaled breath of patients with lung cancer by means of onfiber-derivatisation SPME-GC/MS. Journal of Chromatography $B, 878,2643-2651$.
221. Fuchs, P., Loeseken, C., Schubert, J. K., \& Miekisch, W. (2010). Breath gas aldehydes as biomarkers of lung cancer. International Journal of Cancer, 126, 2663-2670.

222. Song, G., Qin, T., Liu, H., Xu, G. B., Pan, Y. Y., Xiong, F. X., et al. (2010). Quantitative breath analysis of volatile organic compounds of lung cancer patients. Lung Cancer, 67, 227-231.

223. Yan, Y., Wang, Q., Li, W., Zhao, Z., Yuan, X., Huang, Y., et al. (2014). Discovery of potential biomarkers in exhaled breath for diagnosis of type 2 diabetes mellitus based on GC-MS with metabolomics. RSC Advances, 4, 25430-25439.

224. Salehi, S., Nikan, E., Khodadadi, A. A., \& Mortazavi, Y. (2014). Highly sensitive carbon nanotubes- $\mathrm{SnO}_{2}$ nanocomposite sensor for acetone detection in diabetes mellitus breath. Sensors and Actuators B, 205, 261-267.

225. Leopold, J. H., van Hooijdonk, R. T., Sterk, P. J., Abu-Hanna, A., Schultz, M. J., \& Bos, L. J. (2014). Glucose prediction by analysis of exhaled metabolites-A systematic review. BMC Anesthesiology. doi:10.1186/1471-2253-14-46.

226. Storer, M., Dummer, J., Lunt, H., Scotter, J., McCartin, F., Cook, J., et al. (2011). Measurement of breath acetone concentrations by selected ion flow tube mass spectrometry in type 2 diabetes. Journal of Breath Research. doi:10.1088/1752-7155/ 5/4/046011.

227. Phillips, M., Cataneo, R. N., Cheema, T., \& Greenberg, J. (2004). Increased breath biomarkers of oxidative stress in diabetes mellitus. Clinica Chimica Acta, 344, 189-194. 